\title{
Banks' Funding Structure and Earnings Quality
}

\author{
Justin Yiqiang Jin \\ DeGroote School of Business \\ McMaster University \\ E-mail: jinjus@mcmaster.ca \\ Kiridaran Kanagaretnam \\ Schulich School of Business \\ York University \\ E-mail: KKanagaretnam@schulich.yorku.ca \\ Yi Liu \\ School of Business \\ State University of New York at Oswego \\ E-mail: yi.liu@oswego.edu
}




\title{
Banks' Funding Structure and Earnings Quality
}

\begin{abstract}
Using a sample of U.S. public and private banks, we examine the implications of banks' funding strategies for banks' earnings quality. We find that the ratio of core deposits to total liabilities $(C D L)$, our proxy for bank reliance on retail deposits over wholesale funds, is negatively and significantly associated with the magnitude of earnings management through discretionary loan loss provisions $(D L L P)$. This finding is consistent with the arguments that retail deposits are relatively more stable and information-insensitive, reflect a more conservative business model, and attract more intensive monitoring from the Federal Deposit Insurance Corporation (FDIC) than wholesale funds. We find that the inverse relationship between retail funding and earnings management holds for both incomeincreasing and income-decreasing DLLP. Besides, reliance on retail funding decreases the likelihood of meeting-or-beating earnings benchmark, and the extent of income smoothing through loan loss provisions $(L L P)$. In an additional analysis, we find that banks with higher $C D L$ are exposed to lower asset deterioration risk, proxied by large non-performing loans and loan charge-offs during the financial crisis period 2007-2009. Collectively, our results indicate that the banks' funding strategy that relies more on retail deposits as opposed to wholesale funds increases banks' earnings quality.
\end{abstract}

Keywords: Bank Funding Structure; Retail Deposits; Wholesale Funds; Earnings Quality; Discretionary Loan Loss Provisions 


\section{Introduction}

Banks obtain funding through a variety of sources. Traditionally, banks attracted retail deposits, mainly from households. But banks now have increased access to wholesale money market to fund their liquidity through financial and non-financial institutions (Huang and Ratnovski 2011). Van den End and Tabbae (2012) find that banks changed their funding structure to assure themselves of liquidity. Prior literature finds that bank funding structure has important financial implications. For example, during the global financial crisis, wholesale funding was shown to be related to a lower rate of return on assets, greater stock return volatility, and more bank credit supply reduction (Demirguc-Kunt and Huizinga 2010; Dagher and Kazimov 2015). In this paper, we examine an important implication of bank funding structure: the impact of reliance on retail deposits over wholesale funds on banks' earnings quality. Earnings provide information about the features of a firm's financial performance that is relevant to certain decision-making (Dechow et al. 2010). In the banking industry, earnings manipulations can reduce bank stability, the market's valuation of banks, and loan quality (Beatty and Liao 2011; Bushman and Williams 2012; and Huizinga and Laeven 2012). They can also interfere with the private governance and official regulation of banks such as capital requirement violation (Jayaratne and Strahan 1996; Jiang et al. 2016). Nevertheless, little is known on how bank's earnings quality varies with bank's funding structure.

In contrast to non-financial institutions, banks receive funds from two main sources. First, local community households provide banks with a depositor base. Retail deposit accounts are primarily held for their liquidity services and are typically covered by deposit insurance up to some coverage limit (Demirguc-Kunt and Huizinga 2010). ${ }^{1}$ Thus, retail deposits constitute an inexpensive and stable source of long-term funds (Huang and Ratnovski 2008). One drawback of retail deposits, however, is that the

\footnotetext{
${ }^{1}$ A bank's core deposits, or primary deposits, are made by individual or business customers in the bank's market area. In short, they are retail, liquid deposits. Thus, we use the terms core deposits and retail deposits interchangeably. 
local depositor base has a fixed size, and expanding it in the medium term is very expensive (Flannery 1982; Billett and Garfinkel 2004). To supplement insufficient retail deposits, banks may borrow wholesale funds with instruments such as repurchase agreements, federal funds, and bonds (DemirgucKunt and Huizinga 2010; Huang and Ratnovski 2011). Through wholesale money markets, banks can attract cash surpluses not only from households (through money market mutual funds), but also from non-financial firms and other financial institutions (Huang and Ratnovski 2011). However, unlike retail deposits, wholesale funds are usually raised on a short-term rollover basis: they have to be refinanced at the immediate date before final returns are realized, and they do not typically have government deposit insurance coverage. Compared with retail deposits, wholesale funds have several advantages: the amount provided is free from the constraint of local deposit supply, and wholesale lenders can provide market discipline due to their relative sophistication (Calomiris 1999). The dark side of wholesale funds is that they are subject to market-wide liquidity shocks and thus more volatile, and that uninformed wholesale financiers may trigger inefficient bank liquidations (Huang and Ratnovski 2011; Dagher and Kazimov 2015).

Due to distinctive characteristics of retail depositors and wholesale financiers, we posit that banks with different funding structures may have different earnings quality and their incentives to supply high quality accounting information. At first glance, it seems reasonable to predict that bank earnings quality decreases with the share of retail deposits. Generally, retail depositors are less sophisticated and have fewer incentives to acquire bank information to assess risk and to avoid losses because of explicit protection from deposit insurance. Thus, banks with more retail funding may supply lower quality accounting information due to lack of effective monitoring. Although such reasoning seems intuitive, wholesale depositors' ability to understand accounting information is also questionable, and their incentives to monitor bank behaviors may also be mitigated by collateralization. Huang and 
Ratnovski (2011) even argue that wholesale financiers may have little incentive to conduct costly monitoring, and instead simply withdraw funding on the basis of negative and cheap public signals.

The opposite prediction is also considered. That is, banks' earnings quality increases with higher proportion of retail deposits. Previous studies argue that retail deposits are sticky (Gatev and Strahan 2006; Song and Thakor 2007), because of the high switching costs for depositors to change transaction services among banks, and the safety buffer guaranteed by government deposit insurance (Sharpe 1997; Kim et al. 2003). Unlike wholesale funds that are widely subject to market-wide liquidity shocks (Dagher and Kazimov 2015), retail deposits provide banks with greater stability in rolling over the funds needed to generate expected earnings and cash flows. ${ }^{2}$ Because of higher certainty about earnings and cash flows, banks with more retail funding may have a lower propensity to engage in earnings management.

In addition, funding structure reflects different business models. While wholesale funding allows banks to expand rapidly and pursue high returns but risky projects as they arise, banks with a higher proportion of retail deposits are more likely to adopt conservative operation mode and experience less volatile earnings and income smoothing behaviors. Besides, to the extent that retail depositors are stickier and less information-sensitive than wholesale financiers, banks may find it hard to rely on "window" dressed financial information to attract retail deposits. Moreover, retail deposits barely entail any covenants, thus incentives to manipulate accounting information to avoid potential violations of covenants may not be prevalent for banks that rely largely on retail deposits. This is in contrast with wholesale funds, some categories (e.g. subordinated debts (Goyal 2005)) of which have stringent covenant restrictions, providing additional incentives for banks to engage in earnings manipulations. Finally, when a bank carries higher proportion of retail deposits, the insurance risk increases for the

\footnotetext{
${ }^{2}$ Köhler (2015) finds that retail-oriented banks will be significantly less stable if they increase their share of non-deposit funds.
} 
Federal Deposit Insurance Corporation (FDIC), which will then exercise higher scrutiny over bank financial information. Given the channels outlined above, we expect banks' funding structure to influence their earnings quality. However, given the two conflicting predictions, the association between bank funding structure and earnings quality is ultimately an empirical question.

Following Dagher and Kazimov (2015), we use the ratio of core deposits to total liabilities (CDL) as the proxy for banks' retail funding structure. ${ }^{3}$ The higher the $C D L$ for a bank, the greater the reliance on retail deposits, and the less the reliance on wholesale funds. We calculate core deposits as the sum of retail transaction deposits, small amount time deposits (less than $\$ 100,000$ ), money market deposit accounts, and other saving deposits. We use several proxies to measure earnings quality. Our main measure is the magnitude of discretionary loan loss provisions (DLLP). Loan loss provisions $(L L P)$ is an expense item on the bank income statement, reflecting managers' current assessment of the likely level of future losses from defaults on outstanding loans (Cohen et al. 2014). They are the accruals of fundamental importance to bank performance. Specifically, Beatty and Liao (2014) document that LLP has the highest correlation with banks' net income, compared with other net income components (e.g., net interest income, non-interest income and securities gains and losses). And because they are estimates of future loan losses, they also reflect information asymmetry (Beatty and Liao 2014). Often times, managers exploit their information advantage to depart from the normal levels of bank's loan loss provisioning (the single largest accounting accrual estimate in banking) to achieve certain earnings objectives. ${ }^{4}$ The departure from normal levels of $L L P$ is called discretionary loan loss provision (DLLP). If retail deposits are positively associated with bank earnings quality, we should expect banks with higher $C D L$ to be associated with smaller magnitude of $D L L P$. In terms of alternative measures, we use

\footnotetext{
${ }^{3}$ According to BCBS (2011), bank total liabilities include both core deposits and wholesale funds.

${ }^{4}$ Prior research suggests several motives for bank managers' discretionary behavior with respect to LLP, including signaling, capital management, management compensation and income smoothing (Wahlen 1994; Collins et al. 1995; Kanagaretnam et al. 2004; Cheng et al. 2011).
} 
income-increasing and income-decreasing DLLP (i.e., signed accruals), the likelihood of meeting-orbeating earnings benchmark in the form of loss avoidance, and income smoothing through $L L P$.

We collect bank-level annual accounting data from the Commercial Bank Quarterly Call Reports available from the Federal Reserve Bank of Chicago to test the relation between bank liability structure and earnings quality. Our sample consists of 12,083 individual U.S. banks (excluding credit unions) with 146,343 bank-year observations spanning from 1993 to 2012. The sample covers 14 pre-crisis years (1993-2006), 3 crisis years (2007-2009), and 3 post-crisis years (2010-2012). Overall, our results confirm a positive association between banks' earnings quality and their reliance on retail funding over wholesale funding. In particular, we find a smaller magnitude of DLLP for banks with high $C D L$, suggesting that the funding stability from retail deposits improves banks' earnings quality. Using path analysis, we find that the direct effect of funding structure on bank earnings quality is statistically significant and is considerably larger than its indirect effect through mediating factors. This finding holds in all three sub-periods (i.e., pre-crisis, crisis, and post-crisis), and across both banks subject to the Federal Deposit Insurance Corporation Improvement Act (FDICIA) internal control regulations and banks not subject to FDICIA internal control regulations, and across both public and private banks subsamples. In addition, we find that high $C D L$ is associated with a smaller magnitude of signed DLLP, lower likelihood of avoiding losses, and lower propensity to smooth earnings using $L L P$. Our results are robust to controlling for additional bank, state and year effects, and employing instrumental variable to mitigate endogeneity concerns. Collectively, our results indicate that banks' earnings quality is associated with an increase in the proportion of retail deposits.

Our findings contribute to the literature in several important ways. First, we document that reliance on retail deposits over wholesale funds is significantly and positively associated with bank earnings quality. This improves our understanding about the roles of different suppliers of funds in 
affecting banks' earnings quality. The evidence documented in this paper seems to contrast with the existing banking literature, which generally points to the bright side of wholesale funding that wholesale financiers are sophisticated and can provide market discipline (Calomiris and Kahn 1991). In contrast, our findings are more in line with the argument that retail deposits increase the banks' financial stability and diminish opportunistic incentives of bank managers. Second, given that accounting numbers convey important information to a variety of stakeholders, our evidence implies that the banks' funding strategy has externality on other parties (e.g., investors, financial intermediaries, and regulators) beyond retail and wholesale creditors. In this regard, the affected parties may consider alternative ways to be more informative about banks' financial condition. Any rapid shift from traditional retail funding to wholesale funding should draw investors' attention to the quality of banks' financial reporting. This is of importance to regulators, given that our evidence shows that banks' earnings quality deteriorates with less reliance on retail funding. The increased earnings management associated with wholesale funds could directly and negatively affect the capital adequacy ratio, the quality of bank assets, and the level of earnings. As CAMELS ratings are assigned based on ratio analysis of the financial statements and the above factors are important components of the rating system, any manipulation could reduce regulatory monitoring through its influence on CAMELS ratings and thus pose a potential risk to bank stability.

The rest of the paper is organized as follows. Section 2 reviews the literature and develops our hypothesis on the relationship between banks' funding structure and earnings quality. Section 3 explains our research design, including the measures and choices of empirical models to test our hypothesis. Section 4 describes our sample selection and data, including descriptive statistics and Pearson correlations. Section 5 discusses our main results and endogeneity issues. Section 6 provides additional tests on potential channels and other robustness checks. Finally, Section 7 presents our conclusions. 


\section{Literature Review and Hypothesis Development}

Bank managers engage in earnings management for a variety of reasons. First, managers may smooth income due to job security concerns. Kanagaretnam et al. (2003) find that for banks with poor (good) current performance, managers tend to borrow income from (save income for) the future by increasing (reducing) current income through LLP. Second, banks are expected to maintain a certain level of capital ratio, as a higher ratio provides banks with a bigger cushion to write off bad loans in the future. Kim and Kross (1998) show that bank managers with low capital ratios manage LLP to increase the bank capital ratio. Third, given that the cost of financing depends on the perceived risk of banks, managers smooth earnings to reduce the cost of borrowing. Management and existing shareholders benefit if bank can raise funds on more favorable terms (Kanagaretnam et al. 2003). Fourth, banks manage earnings to signal private information about future prospects. Beaver et al. (1989) suggest that management perceives the earnings power of the bank to be sufficiently strong that it can withstand a hit of additional loan loss provisions. Consistent with the signaling hypothesis, Wahlen (1994) documents a positive relation between unexpected loan loss provisions and future pre-loan-loss earnings changes. Fifth, banks' listing status may also influence banks' incentives to manage earnings. For example, Beatty and Harris (1999) argue that public and private firms have different levels of information asymmetry and different proportions of long-run investors, therefore, may differentiate in earnings management incentives. Finally, high audit quality may constrain earnings management, to the extent that Big 4 auditors have higher expertise and higher independence (Kanagaretnam et al. 2010).

How banks' earning management is driven by the business model of a bank is also important in light of recent focus on the importance of the business model that the bank chooses (see e.g. Boot and Ratnovski 2016) and its relationship with the risk that the bank is pursuing. The bank's model of risk taking might then be related to the bank's prudence in earnings management practices. Boot and 
Ratnovski (2016) study the interaction between relationship banking and short-term arm's length activities of banks, called trading. They show that a bank can use the franchise value to expand the scale of trading, but may allocate too much capital to trading. This effect is reinforced when trading is used for risk shifting.

Depositors discipline banks by withdrawing funds when they believe that managers take on more risks than deemed acceptable (Davenport and McDill 2006; Martinez Peria and Schmukler 2001). Bennett et al. (2015) find that depositors discipline banks far ahead to signal the need for corrective actions in the recent financial crisis. Prior literature also finds that an increase in deposit insurance is associated with greater bank risk-taking and greater likelihood of banking crises (Berger and Turk-Ariss 2015; Demirguç-Kunt and Detragiache 2002; Lambert et al. 2017). Given that deposit insurance mainly targets retail deposits, these indirect evidence indicates that retail deposits and deposit insurance fulfill a complementing role in monitoring banks.

There are two competing arguments on how banks' funding structure could affect their earnings quality. On the one hand, a higher proportion of retail deposits is potentially negatively associated with banks' earnings quality if retail depositors have a lower demand for information about bank managerial behaviors. This is likely because, compared with wholesale depositors, retail depositors have fewer incentives and resources to monitor and discipline bank behaviors (Calomiris and Kahn 1991). In contrast to wholesale depositors who are typically uninsured, retail depositors benefit from explicit government deposit insurance. For example, FDIC covers traditional retail deposit accounts such as checking and savings accounts, money market deposit accounts, and certificates of deposits up to $\$ 250,000$ per depositor, per FDIC-insured bank, per ownership category (FDIC 2015). ${ }^{5}$ Therefore, retail depositors are at lower risk of realizing losses, and may be less incentivized to utilize bank financial

\footnotetext{
${ }^{5}$ In 2008, Congress passed a law increasing the FDIC coverage from $\$ 100,000$ to $\$ 250,000$, but only through 2013 . Then in 2010 , the lawmakers approved a permanent increase to the $\$ 250,000$ coverage amount (FDIC 2015).
} 
information and assess risk than wholesale depositors. This is consistent with the findings of Martinez Peria and Schmukler (2001) that uninsured depositors impose stronger monitoring as they are more likely to incur losses in the case of bank failure. Moreover, retail depositors may not possess the sophisticated financial skills to gather and process bank financial information as wholesale depositors (Macey and Miller 1988; Calomiris and Kahn 1991; Demirguc-Kunt and Huizinga 2004), making them at a disadvantage in monitoring banks. As a result, banks with a higher proportion of retail deposits may simply supply low-quality accounting information to retail depositors.

On the other hand, we argue that wholesale depositors may not be effective in imposing financial reporting discipline on banks. ${ }^{6}$ The banking literature shows that even sophisticated depositors may be fooled by bank opacity. Drawing on the evidence of Iyer et al. (2016), Gallemore (2013) argues that despite their knowledge, sophisticated depositors are unable to deduce the bank problems from released financial information, thus they continue to roll over their debt funding to the troubled banks without inducing any bank run. In addition, some types of lending are not really risky (and sometimes safer) to wholesale lenders, even if they are not insured. For example, the repurchase agreement (repo), one type of wholesale lending, is a collateralized transaction. If the bank defaults on the borrowing, the repo lenders have the right to terminate the agreement and keep or sell the collateral, the value of which is usually higher than the amount of repo deposit itself (Gorton and Metrick 2012). Given this haircut, repo lenders may have very little incentive to monitor banks through complicated process of financial reporting examination, as they can simply sell the underlying collateral to compensate for any of the losses that they may incur. Furthermore, even wholesale financiers, whose transactions are not collateralized, may not bother going through complicated bank financial reports and instead, they may

\footnotetext{
${ }^{6}$ Drawing on the evidence of the subprime crisis, Ackermann (2008) argues that a robust deposit base combined with a funding structure that avoids significant currency and maturity mismatches has proven to be beneficial for the stability of financial institutions.
} 
just withdraw funding in response to negative public signals, triggering inefficient bank liquidations (Huang and Ratnovski 2011).

Given the counter arguments, we expect that the opposite scenario is more likely to hold empirically. That is, higher proportion of retail deposits would be positively associated with higher earnings quality. To the extent that deposit insurance funds are generally not enough to cover all deposits, retail depositors may still have some concerns or incentives to monitor banks. Some early evidence from prior literature suggests that retail depositors monitor banks' operations and react to negative non-financial information of banks. For example, Homanen (2018) documents that U.S. banks, who finance the highly controversial Dakota Access Pipeline, have significant decreases in retail deposit growth, especially for branches located closest to the pipeline. Using a dataset on tax evasion, corruption and environmental scandals, Homanen (2018) also shows that negative retail depositors' reaction to bank scandals is a widespread phenomenon. Additionally, indirect evidence also suggests wholesale funding affects managerial incentives in the banking industry. For example, Demirguc-Kunt and Huizinga (2010) find that wholesale funding lowers the rate of return on assets and increases financial fragility, as measured by distance to default and the volatility of bank stock returns. Similarly, Raddatz (2010) documents that wholesale funding has a negative effect on the performance of their stock prices after the outbreak of the crisis. In addition, U.S. retail funded banks continue to lend relative to wholesale funded banks during the global financial crisis (Dagher and Kazimov 2015). Dinger and Graig (2013) find that banks facing volatile loan demand tend to fund loans with larger shares of wholesale rather than retail liabilities.

In addition, previous studies document that retail deposits are a more stable source of funding for banks (Gatev and Strahan 2006; Song and Thakor 2007), because retail depositors face higher turnover costs to change transaction services among banks (Sharpe 1997; Kim et al. 2003). The government 
deposit insurance coverage also adds to retail depositors' stickiness to their current banks. This is in contrast with wholesale funds, which are usually raised on a short-term (often daily) rollover basis, and more vulnerable to market-wide liquidity shocks (Dagher and Kazimov 2015). Given the bank funding stability arising from retail depositors, we posit that banks with a greater reliance on retail deposits should have a lower propensity to engage in earnings management and have fewer problems in rolling over the funds needed to generate expected earnings and cash flows than their counterparts that rely more on wholesale funds.

Under wholesale funding strategy, banks could expand rapidly without being constrained by the local deposit supply. For example, Demirguc-Kunt and Huizinga (2010) find that wholesale funding is associated with larger and fast-growing institutions. This would make banks exploit valuable investment opportunities as they arise (Huang and Ratnovski 2011). But at the same time, wholesale funding may also affect the riskiness of banks. This is evidenced by Demirguc-Kunt and Huizinga (2010), who document that wholesale funding increases the stock volatility of banks, and Kohler (2015), who finds that banks' income volatility increases with a larger share of non-deposit funding. As earnings become volatile, bank with a higher proportion of wholesale funding would have more incentives to manipulate accounting numbers to smooth their earnings.

In comparison, retail deposit funding strategy leads banks to pursue more conservative expansion by taking a branch-centric approach, including in-store branches (Hirtle and Stiroh 2006). Furthermore, Hirtle and Stiroh (2006) find that an increased focus on retail banking across U.S. banks is linked with significantly lower equity market and accounting returns for all banks, and lower volatility for large bank holding companies. This implies that retail banking is a low return, but a stable line of business. When banks with retail deposit funding structure have less volatile earnings, they are less incentivized to engage in income smoothing and earnings management activities. 
Moreover, to the extent that retail depositors are more stable and less sensitive to information than wholesale depositors (Forti and Schiozer 2015), banks should have fewer incentives to manipulate accounting information when they largely rely on retail depositors. Retail banks that rely more on core deposits tend to have strong relationships with their depositors, which may allow the depositors to better assess risk (Loutskina and Strahan 2011). Such relationship lending is usually based on "soft" data such as personal connections and reputation (Allen et al. 2004) and could lead bank managers to disclose more private financial information to their major depositors. As a result, the strong relationship lending could reduce the information asymmetry between banks and their major depositors. For example, Puri and Rocholl (2008) find that instead of discriminating against retail depositors, banks tend to treat their retail depositors well by informing their customers of good deals. Specifically, they find that lead underwriters' retail customers benefit as they demand and end up with significantly more of the highly underpriced issues.

In an attempt to understand why bank managers have greater incentives to pass on high-quality accounting information and financial disclosures to retail depositors, Puri and Rocholl (2008) find that banks' incentives come from the benefits banks obtain through retail cross-selling, i.e., both brokerage accounts and consumer loans increase significantly. Collectively, we argue that the relationship lending that banks develop with their major retail customers leads to high-quality accounting information and disclosures that can help banks maintain such important relationships.

Furthermore, from the perspective of debt covenant, banks may manipulate accounting information in order to avoid triggering potential covenant violations. Since retail deposits barely attach any covenants, banks may have very little incentive to manipulate accounting numbers to avoid covenant violations and to please retail depositors. In contrast, some categories of wholesale funds (e.g., 
subordinated debt contracts) entail very stringent covenant restrictions (Goyal 2005), providing additional motivation for banks to manipulate accounting information.

Finally, when a bank carries higher proportion of retail deposits, the insurance risk increases for FDIC and the bank may be subject to greater monitoring by FDIC. According to FDIC (2015), "the amount each institution is assessed is based upon statutory factors that include the balance of insured deposits as well as the degree of risk the institution poses to the insurance fund." Higher proportion of retail funds will automatically increase the balance of insured funds and pose greater risk to FDIC. To reduce its risk, FDIC will exercise higher scrutiny over banks and, therefore, monitor the financial information more closely. Given the competing arguments outlined above, the association between bank funding structure and earnings quality is ultimately an empirical question.

\section{Research Design}

Following Dagher and Kazimov (2015), we employ the core deposits to liabilities ratio $\left(C D L_{i t}\right)$ as the measure of retail deposits. ${ }^{7} C D L$ is defined as the sum of retail deposits (including certificates of deposit) and debt securities issued that are held by retail customers scaled by total liabilities. We calculate retail deposits as the sum of transaction deposits, small amount time deposits (less than $\$ 100,000)$, money market deposit accounts, and other saving deposits. The higher the $C D L$, the greater reliance on retail deposits and the less reliance on wholesale funds by banks.

To proxy for bank earnings quality, we primarily focus on the magnitude of discretionary loan loss provisions $(D L L P)$. Loan loss provisions $(L L P)$ are an expense item in a typical bank income statement, reflecting bank managers' current estimates of future losses from defaults on outstanding

\footnotetext{
${ }^{7}$ Note that Dagher and Kazimov (2015) use the term core deposits for retail deposits. Also note that BCBS (2011) use the wholesale funds to liabilities ratio (WDL) to measure bank funding structure, where the wholesale deposits to liabilities ratio is defined as the sum of wholesale funds (total liabilities less retail deposits) scaled by total liabilities. But since there is a mechanically inverse relationship between $C D L$ and $W D L$, we only focus on $C D L$ as our main proxy for bank funding structure.
} 
loans (Cohen et al. 2014). They are also the largest component among accruals in banks, thus affording bank managers wide latitude in its use (Kanagaretnam et al. 2010; Beatty and Liao 2014). Prior banking research finds that financial institutions may deviate from their normal levels of loan loss provisioning to employ abnormal loss provisioning for opportunistic reasons of managing earnings (Kanagaretnam et al. 2010; Cohen et al. 2014; Kanagaretnam et al. 2015). The abnormal (or discretionary) component of loan loss provisions is also called DLLP. Beatty and Liao (2014) document that DLLP is likely to be an earnings management tool, as they document that a greater magnitude of DLLP is associated with increased earnings restatements and comment letters from the U.S. Securities and Exchange Commission (SEC).

To empirically measure DLLP, we first estimate the non-discretionary component of $L L P$ by regressing $L L P$ on the variables that account for bank's normal loan loss provisioning behavior. The part of $L L P$ unaccounted for by these determinants is taken as DLLP (i.e., the residuals from the first stage regression). Specifically, we follow the model from Beatty and Liao (2014) to run the OLS regressions of $L L P$ using Equation (1a).

$L L P_{i t}=\alpha_{0}+\alpha_{1} \Delta N P L_{i t+1}+\alpha_{2} \Delta N P L_{i t}+\alpha_{3} \Delta N P L_{i t-1}+\alpha_{4} \Delta N P L_{i t-2}+\alpha_{5} S I Z E_{i t-1}+\alpha_{6} \Delta L O A N_{i t}+$ $\alpha_{7} \Delta S T_{-} G D P_{i t}+\alpha_{8} \Delta S T_{-} H P I_{i t}+\alpha_{9} \Delta S T_{-} U R_{i t}+S T_{-} D U M M I E S+Y E A R_{-} D U M M I E S+\varepsilon_{i t}$

where $L L P_{i t}$ is loan loss provisions scaled by beginning total loans for bank $i$ in year $t ; \Delta N P L_{i t}$ is change in non-performing loans during year $t$ scaled by beginning total loans; $S I Z E_{i t}$ is natural logarithm of total assets in year $t ; \triangle L O A N_{i t}$ is change in total loans during year $t$ scaled by beginning total assets; $\Delta S T_{-} G D P_{i t}$ is change in GDP of the state where the bank's headquarter is located during year $t ; \Delta S T_{-} H P I_{i t}$ is change in the return of the house price index of the state where the bank's headquarter is located during year $t ; \Delta S T_{-} U R_{i t}$ is change in the state unemployment rate of the state where the bank's headquarter is located during year $t$; ST_DUMMIES and YEAR_DUMMIES are state 
and year dummy variables to account for state and year fixed effects. ${ }^{8}$ The fitted value in Equation (1a) represents the non-discretionary $L L P$, and the residual is treated as $D L L P$. This model allows for changes in non-performing loans in four consecutive periods (i.e., $\Delta N P L_{i t+1}, \Delta N P L_{i t}, \Delta N P L_{i t-1}$, and $\left.\triangle N P L_{i t-2}\right)$, because an increase in non-performing loans will require a higher $L L P$ and banks might use historical, current and forward-looking information on non-performing loans to select $L L P$. The model also includes bank size $\left(S I Z E_{i t-1}\right)$ and change in loans $\left(\triangle L O A N_{i t}\right)$, because official supervisory oversight and private sector monitoring could vary with banks size and an increase in loans might be associated with a decrease in loan quality.

And to further corroborate that our results are not driven by the choice of this model, we also employ an alternative form, Equation (1b), proposed by Kanagaretnam et al. (2010), which relies on largely different determinant variables.

$L L P_{i t}=\alpha_{0}+\alpha_{1} L O A N_{i t}+\alpha_{2} \Delta L O A N_{i t}+\alpha_{3} L L A_{i t-1}+\alpha_{4} C O_{i t}+\alpha_{5} N P L_{i t-1}+\alpha_{6} \Delta N P L_{i t}+\alpha_{7} C L_{i t}+$ $\alpha_{8} R L_{i t}+\alpha_{9} I L_{i t}+\alpha_{10} A L_{i t}+\alpha_{11} D L_{i t}+S T_{-} D U M M I E S+Y E A R_{-} D U M M I E S+\varepsilon_{i t}$

where $L O A N_{i t}$ is total loans scaled by total assets in year $t ; L L A_{i t-1}$ is loan loss allowance scaled by total loans in year $t-1 ; C O_{i t}$ is loan charge-offs scaled by beginning total loans in year $t ; N P L_{i t-1}$ is non-performing loans scaled by total loans in year $t-1 ; C L_{i t}$ to $D L_{i t}$ are loan categories, including commercial and industrial loans $\left(C L_{i t}\right)$, real estate loans $\left(R L_{i t}\right)$, individual loans $\left(I L_{i t}\right)$, agriculture loans $\left(A L_{i t}\right)$, and loans to depository institutions $\left(D L_{i t}\right)$. Beginning balance of non-performing loans $\left(N P L_{i t-1}\right)$ accounts for the fact that problems with the loan portfolio will require higher loss provisions. Current loan charge-offs $\left(\mathrm{CO}_{i t}\right)$ are included because they can influence expectations of the collectability of current loans and hence current $L L P . L O A N_{i t}$ is included because higher level of loans will require higher provisions. The model also includes loan category variables to control for differences in loan

\footnotetext{
${ }^{8}$ In a robustness test, we include squared SIZE in the first stage regression models (1a) and (1b), and our results still hold. Therefore, non-linearity in SIZE does not change our findings.
} 
composition that also likely contribute to differences in risk. For example, banks with a higher proportion of commercial and real estate loans are likely to have higher LLP than banks with a higher proportion of consumer loans (Kanagaretnam et al. 2010).

The residuals of Equations (1a) and (1b) are computed as DLLP. We use the absolute value of the residuals $\left(A B S D L L P_{-} A_{i t}\right.$ and $\left.A B S D L L P_{-} B_{i t}\right)$ from Equations (1a) and (1b) as our main proxies for bank earnings quality. The higher the value of $A B S D L L P_{-} A_{i t}$ and $A B S D L L P_{-} B_{i t}$, the lower the earnings quality of banks. In our baseline analysis, we focus on the absolute value of the residuals. But in the additional analysis, we further divide DLLP based on their signs, and investigate the funding implication for both income-increasing and income-decreasing DLLP, respectively.

To test the influence of bank funding strategy on earnings quality, we estimate the following regression models.

$$
\begin{aligned}
& \text { ABSDLLP_A } A_{i t}=\alpha_{0}+\alpha_{1} C D L_{i t-1}+\alpha_{2} \text { SIZE }_{i t}+\alpha_{3} \text { SIZE }_{i t}^{2}+\alpha_{4} L_{O A N_{i t}}+\alpha_{5} \text { CAPR }_{i t}+\alpha_{6} E B P_{i t}+ \\
& \alpha_{7} \text { LLP }_{i t-1}+\alpha_{8} L I Q U I D_{i t}+\alpha_{9} V_{\text {VOROA }}+\alpha_{10} \Delta E B P_{i t+1}+\alpha_{11} \text { PUBLIC }_{i t}+\alpha_{12} B I G 4_{i t}+ \\
& \text { BANK_STATE_YEAR_EFFECTS }+\varepsilon_{i t}
\end{aligned}
$$

$A B S D L L P_{-} B_{i t}=\alpha_{0}+\alpha_{1} C D L_{i t-1}+\alpha_{2} S_{I Z E_{i t}}+\alpha_{3} S I Z E_{i t}^{2}+\alpha_{4} L O A N_{i t}+\alpha_{5} C A P R_{i t}+\alpha_{6} E B P_{i t}+$ $\alpha_{7} L L P_{i t-1}+\alpha_{8} L_{I Q U I D} D_{i t}+\alpha_{9}$ VOLROA $_{i t}+\alpha_{10}$ EEBP $_{i t+1}+\alpha_{11}$ PUBLIC $_{i t}+\alpha_{12} B I G 4_{i t}+$ BANK_STATE_YEAR_EFFECTS $+\varepsilon_{i t}$

where $A B S D L L P_{-} A_{i t}$ and $A B S D L L P_{-} B_{i t}$ are the absolute value of discretionary $L L P$ from Equation (1a) or Equation (1b), respectively. Our primary variable of interest is the bank funding structure variable, $C D L_{i t-1}$, defined as the ratio of core deposits to total liabilities in year $t-1$. We use $C D L_{i t-1}$, because we expect the funding structure to affect bank earnings quality with a lag. In addition, $C D L_{i t-1}$ helps to mitigate concerns resulting from reverse causality. Based on the prediction that banks have fewer 
incentives to use discretionary $L L P$ to attract retail deposits and to avoid covenants violations, we expect that the coefficient on $C D L_{i t-1}$ is significantly negative. Following Altamuro and Beatty (2010) and Kanagaretnam et al. (2014), we include a set of financial variables in the regressions, including bank size $\left(S I Z E_{i t}\right)$, bank loans to total deposits $\left(L O A N_{i t}\right)$ to control for the need for external financing, capital ratio $\left(C A P R_{i t}\right)$ to control for capital management, earnings before LLP $\left(E B P_{i t}\right)$ to control for income smoothing incentives, lagged LLP $\left(L L P_{i t-1}\right)$, liquid assets $\left(L I Q U I D_{i t}\right)$, volatility of return on assets $\left(V_{O L R O A_{i t}}\right)$ to control for bank risk, change in earnings before LLP $\left(E B P_{i t+1}\right)$ to control for signaling, public bank listing status $\left(P U B L I C_{i t}\right)$, and Big 4 firm audit status $\left(B I G 4_{i t}\right)$ to control for audit quality. We also include the square of bank size $\left(S I Z E_{i t}^{2}\right)$ to control for the non-linearity in the relationship between bank size and earnings quality in our model. ${ }^{9}$ In addition, we control for bank, state, and year fixed effects. To account for the possibility that the error terms might be correlated, we cluster the standard errors at the bank level.

In addition to the magnitude of $D L L P$, we use the magnitude of signed accruals including income-increasing DLLP ( $A B S I I D L L P_{-} A_{i t}$ and $\left.A B S I I D L L P_{-} B_{i t}\right)$ and income-decreasing DLLP ( $A B S I D D L L P_{-} A_{i t}$ and $\left.A B S I D D L L P_{-} B_{i t}\right)$, the incidence of loss avoidance $\left(L S A V_{i t}\right)$ to capture whether a bank meets-or-beats earnings benchmark, and the contemporaneous relationship between $L L P_{i t}$ and $E B P_{i t}$ to measure the extent to which $L L P$ is used to smooth earnings.

\section{Sample and Data}

Banks' financial data are obtained from the Call Reports (Report of Condition and Income) that banks file with the Federal Reserve, the Federal Deposit Insurance Corporation, or the Office of the

\footnotetext{
${ }^{9}$ Prior literature has studied potential non-linearities of firm size in various regression models (e.g., Bertschek and Entorf 1996; Siggelknow 2003; Amato and Amato 2007, 2012). These studies suggest that the effect of size on various dependent variables is non-linear and recommend adding linear and squared terms in the regressions.
} 
Comptroller of the Currency. ${ }^{10}$ The Call Reports data have the advantage of providing financial information not only for public banks but also for private banks, which comprise the majority of banks in our study. The data are available at the Federal Reserve Bank of Chicago website. We omit all credit unions, as they typically receive no wholesale funds. The sample encompasses the period 1993-2012, including 14 pre-crisis years (1993-2006), 3 crisis years (2007-2009), and 3 post-crisis years (20102012). In our baseline analysis, we focus on the entire period of 20 years. In additional analyses, we will look at the three sub-periods separately. We then delete observations without enough financial information to construct our variables, and all bank-level continuous variables are winsorized at the top and bottom 1 percentiles to mitigate the effects of any outliers. Our final sample consists of 12,083 individual banks and 146,343 bank-year observations.

We report the descriptive statistics for the variables used in the regression analysis in Table 1. During the whole sample period, the mean of absolute values of DLLP ( $A B S D L L P{ }_{-} A_{i t}$ and ABSDLLP_ $B_{i t}$ ) calculated from Equations (1a) and (1b) are 0.002 and 0.001 , respectively. The mean values of the magnitude of income-increasing DLLP (ABSIIDLLP_A $A_{i t}$ and $\left.A B S I I D L L P \_B_{i t}\right)$ are 0.001 and 0.001 , whereas the mean values of the magnitude of income-decreasing DLLP (ABSIDDLLP_ $A_{i t}$ and $\left.A B S I D D L L P_{-} B_{i t}\right)$ are 0.003 and 0.001 . Amongst the sample banks, $6.3 \%$ of them report small positive earnings. On the liability side of the sample banks, similar to Dagher and Kazimov (2015), we find that the average ratio of core deposits to total liabilities $\left(C D L_{i t-1}\right)$ is $81.2 \%$, suggesting that banks are largely funded by retail deposits rather than wholesale deposits. On the asset side, we find that bank loans $\left(L O A N_{i t}\right)$ are $72.9 \%$ of bank deposits, and $5.8 \%$ of bank assets are liquid assets (LIQUID $\left.i t\right)$.

[Table 1]

\footnotetext{
${ }^{10}$ The Call reports provide bank quarterly data but not annual data. We need to select the 4th quarter data as the annual data to do our annual regression tests. The 4th quarter data from the Call Reports is an aggregated annual dataset. The Call Reports variable RSSD9999 identifies the reporting date. We identify annual financial information from call reports by setting the last four digits of the variable RSSD9999 to be 1231. 1231 means December 31.
} 
We present the Pearson correlation matrix of the dependent and independent variables in Panel A of Table 2. The core deposit ratio $C D L_{i t-1}$ is negatively and significantly correlated with $A B S D L L P \_A_{i t}$, $A B S D L L P_{-} B_{i t}, A B S I I D L L P_{-} A_{i t}, A B S I I D L L P_{-} B_{i t}, A B S I D D L L P A_{i t}, A B S I D D L L P_{-} B_{i t}$, and $L S A V_{i t}$ at the $1 \%$ level, suggesting that banks with heavy reliance on retail deposits are associated with less earnings management through discretionary LLP (either income-increasing or income-decreasing), and lower propensity of avoiding losses. Furthermore, we find that the measures of DLLP and loss avoidance have a significantly positive correlation with each other, consistent with low earnings quality banks engaging in more loss provision management, and meeting-or-beating earnings benchmarks.

In the previous section, we argue that retail deposits are relatively sticky, providing a stable source of funds for banks. To illustrate this point, we compare the Pearson correlation matrix of unscaled core deposits $(C D)$ and wholesale funds $(W F)$, and their forward and lagged values in Panel B of Table 2. As shown in the table, $C D_{i t}$ has a Pearson correlation coefficient of 0.952 with $C D_{i t-1}, 0.879$ with $C D_{i t-2}$, and 0.966 with $C D_{i t+1}$. This is in contrast with $W F_{i t}$, which has a correlation coefficient of 0.931 with $W F_{i t-1}, 0.829$ with $W F_{i t-2}$, and 0.937 with $W F_{i t+1}$. Based on the Pearson correlations of their serial values, it is reasonable to argue that core deposits are more stable than wholesale funds for banks.

\section{[Table 2]}

In Table 3, we present the univariate comparisons of the mean of the absolute value of $D L L P$ and signed $D L L P$, and the incidence of loss avoidance for banks with above median $C D L$ and those below median $C D L$ for different sample partitions. We find that the mean values of $A B S D L L P \_A_{i t}$ and $A B S D L L P_{-} B_{i t}, A B S I I D L L P_{-} A_{i t}$ and $A B S I I D L L P_{-} B_{i t}, A B S I D D L L P_{-} A_{i t}$ and $A B S I D D L L P_{-} B_{i t}$, and $L S A V_{i t}$ are lower for banks with high $C D L$ than for banks with low $C D L$. We next discuss the results of the multivariate analysis. 
[Table 3]

\section{Regression Results}

\subsection{Main Regression Results}

We provide the regression results for estimating DLLP in Table 4. Panels A and B report the regression results of using Equations (1a) and (1b) to estimate $D L L P$, respectively. Most estimated coefficients are consistent with those reported in Beatty and Liao (2014) and Kanagaretnam et al. (2010). In Panel A, we find significant and positive coefficients on $N P L_{i t+1}, N P L_{i t}, N P L_{i t-1}$, and $N P L_{i t-2}$, suggesting that banks use both forward-looking and past information on non-performing loans in estimating normal portion of $L L P$. Panel B reports that $L L A_{i t-1}$ is negatively associated with $L L P_{i t}$ at the $1 \%$ level, in line with the argument that a high level of beginning loan loss allowance will require a bank to recognize a lower level of $L L P$ in the current period. The residuals from equations (1a) and (1b) represent $D L L P \_A$ and $D L L P \_B$, respectively. And negative (positive) residuals represent the incomeincreasing (income-decreasing) DLLP.

[Table 4]

Table 5 presents the OLS estimation relating bank funding structure to ABSDLLP using Equations (2a) and (2b), respectively, where we control for bank, state and year fixed effects. ${ }^{11}$ Of primary interest is the coefficient of $\alpha_{1}$ on $C D L_{i t-1}$. A negative sign for $\alpha_{1}$ indicates that retail deposits are negatively associated with earnings management. Consistent with this expectation, we find that $C D L_{i t-1}$ is negatively and significantly related with $A B S D L L P \_A_{i t}$ at the $1 \%$ level $(t$-value $=-11.48)$. We also find that $C D L_{i t-1}$ is negatively and significantly related with $A B S D L L P_{-} B_{i t}$ at the $1 \%$ level ( $t$ value $=-14.82$ ). In terms of economic magnitude of the impact of retail deposits on discretionary loan

\footnotetext{
${ }^{11}$ Banks may possess some static innate characteristics that are unobservable and hence not captured by any of the control variables included in our main regressions. To the extent that bank earnings quality and funding strategy are simultaneously determined by the omitted static innate characteristics, the coefficients reported in our main results may be biased. To mitigate this concern, we estimate the baseline regressions by controlling for bank fixed effects.
} 
loss provisions, a one standard deviation increase in $C D L$ is associated with a $5.6 \%(11.2 \%)$ decrease in ABSDLLP_A (ABSDLLP_B), which indicates that the economic magnitude of the impact of $C D L$ on ABSDLLP is substantial. ${ }^{12}$ The results support the arguments that retail deposits represent a more stable source of funds for banks and that banks have fewer incentives to distort accounting information to contract with retail depositors. With regard to the control variables, we find that $L L P_{i t-1}, L I Q U I D_{i t}$, and $V O L R O A_{i t}$ have a significantly positive relationship with the two accruals manipulation measures, indicating that banks with large lagged loan loss provisions, higher liquid assets and higher risks engage in more accruals manipulation. In contrast, we find that $S I Z E_{i t}, C A P R_{i t}$ and PUBLIC $i t$ are negatively associated with $A B S D L L P_{-} A_{i t}$ and $A B S D L L P_{-} B_{i t}$, implying that larger banks, banks with higher capital adequacy, and public banks conduct less accruals management than smaller banks, banks with lower capital adequacy, and private banks.

[Table 5]

\subsection{Endogeneity Tests}

It is possible that influences on banks' earnings quality could cause banks to adjust their funding structure. In this case, the OLS estimation of our empirical models may have endogeneity bias due to reverse causality. Although in the baseline regressions we use the lagged value of $C D L$ which mitigates some of the endogeneity concern, we employ an instrumental variable approach to further address endogeneity issues.

Prior accounting and finance literature usually regards organization age as a valid instrument (e.g., Harjoto and Jo 2011; DeFond et al. 2016). We argue that a bank's age can be viewed as exogenous, given that the bank establishment was a decision made in prior years. Furthermore, we argue that longlived banks should be more effective in attracting retail depositors and maintain a relatively high

\footnotetext{
${ }^{12}$ The economic magnitude of the impact of $C D L$ on $D L L P=$ one standard deviation of $C D L *$ coefficient / mean of the dependent variable $A B S D L L P$. Thus, the economic impact of $C D L=(0.112 *(-0.001)) / 0.002=-0.056$ for $A B S D L L P \_A$, and $(0.112 *(-0.001)) / 0.001=-0.112$ for ABSDLLP_B.
} 
percentage of retail deposit funding for two reasons. First, long-lived banks are more reliable and have less financial risks than younger banks in the eyes of retail depositors. Second, retail customers find it costly to walk away from a well-established lending relationship due to the high switching cost. Following this line of reasoning, we use the bank age $\left(A G E_{i t}\right)$ as our instrumental variable for retail deposit funding variable $\left(C D L_{i t}\right)$. More specifically, we define $A G E_{i t}$ as the natural logarithm of 1 plus the number of years since the bank became active. We then estimate the first-stage regression model using Equation (3) to predict the endogenous retail deposit funding variable $C D L_{i t}$, and use the predicted value of $C D L_{i t}$ from the first-stage regression to test the relationship between bank funding structure and earnings quality in the second stage regression. We expect $A G E_{i t}$ to have a significant and positive relationship with $C D L_{i t}$ in Equation (3).

$C D L_{i t}=\alpha_{0}+\alpha_{1} A G E_{i t}+\alpha_{2} S I Z E_{i t}+\alpha_{3} S I Z E_{i t}^{2}+\alpha_{4} L O A N_{i t}+\alpha_{5} C A P R_{i t}+\alpha_{6} E B P_{i t}+\alpha_{7} L L P_{i t-1}+$ $\alpha_{8}$ LIQUID $_{i t}+\alpha_{9}$ VOLROA $_{i t}+\alpha_{10} \Delta E B P_{i t+1}+\alpha_{11}$ PUBLIC $_{i t}+\alpha_{12}$ BIG $_{i t}+$ $B A N K_{-} S T A T E_{-} Y E A R_{-} E F F E C T S+\varepsilon_{i t}$

where $A G E_{i t}$ is defined as the natural logarithm of 1 plus the number of years since the bank became active.

The results of the instrumental variable regression are reported in Table 6, where we tabulate both the first-stage (Panel A) and the second-stage regression results (Panel B). We also conduct Hausman (1978) tests to verify the existence of endogeneity. In the first-stage regression, as we have predicted, $A G E_{i t}$ is positively and significantly associated with $C D L_{i t}$ at the $1 \%$ level, implying that older banks have higher proportion of retail deposits than younger banks. Turning attention to the second stage, Panel B reports a negative and significant coefficient ( $t$-value $=-7.66$ and -10.69 , respectively) on the predicted value of core deposit ratio, $P R E D_{-} C D L_{i t-1}$, in the regressions of $A B S D L L P_{-} A_{i t}$ and $A B S D L L P_{-} B_{i t}$. The results show that the reliance on retail funding relative to 
wholesale funding is associated with higher earnings quality, consistent with the argument that retail deposits represent a more stable source of funds for banks. Therefore, bank managers have less incentives to manipulate earnings numbers to attract funding from retail depositors.

[Table 6]

\section{Additional Analyses}

\subsection{Test of Retail Deposit Stability Hypothesis}

In the hypothesis development, we predict several channels through which retail deposits improve bank earnings quality. One important channel is that retail deposits are more stable source of funding, reducing the necessity for earnings management. If this channel is viable, we should find stronger results for banks with small changes in retail deposits, as retail deposit funding is more stable for these banks. Meanwhile, we should find rather weak results for banks with big changes in deposits which are more volatile in retail deposit funding. We classify our sample banks into decile groups based on the absolute value of the change rate of core deposits $\left(\left|C D_{i t+1}-C D_{i t}\right| / C D_{i t}\right)$. The greater the value of the change rate is, the lower the funding stability of retail deposits is. We report the regression results for the top and bottom decile retail deposit funding stability in Panels A and B of Table 7, respectively. In Panel A, we find that the coefficients on $C D L_{i t-1}$ are -0.002 and -0.001 for $A B S D L L P \_A$ and ABSDLLP_B, which are significantly negative for top decile retail deposit stability banks, suggesting that banks with more stable retail deposits have less earnings manipulation. For the bottom decile retail

deposit stability banks, in Panel $\mathrm{B}$, we find an insignificant coefficient on $C D L_{i t-1}$ for $A B S D L L P \_A$ and a marginally significant but positive coefficient on $C D L_{i t-1}$ for $A B S D L L P \_B$, implying that very volatile retail deposits are not necessarily associated lower bank accruals manipulation through LLP. Therefore, we confirm that retail deposit funding stability is an important channel through which retail depositors affect bank earnings quality. 
[Table 7]

\subsection{Test of FDIC Insurance Coverage Hypothesis}

In 2008, Congress passed a law increasing the FDIC coverage from $\$ 100,000$ to $\$ 250,000$. We argue that increasing the deposit insurance coverage limit would make retail depositors feel safer, and, hence, retail funding would become more stable. In addition, the increase in insurance amount poses greater risk of loss to FDIC, which, in turn, may exercise more scrutiny over bank financial reporting. Taken together, we predict that the positive effects of retail deposits on bank earnings quality would be stronger following the increase in deposit insurance coverage limit. One potential caveat with the use of FDIC regulation change in insurance coverage limit is that such change might be cofounded by other events, noticeably the financial crisis. However, to the extent that the financial crisis deteriorates the reporting environment and imposes greater liquidity constraint on wholesale funding, we could still expect that banks with higher reliance on retail funding are associated with higher earnings quality in the post-crisis period. Given this, we choose a 6-year window (2005-2010) to test the effect of the FDIC regulation change. Specifically, we estimate the following OLS regression model:

$$
\begin{aligned}
& A B S D L L P_{i t}=\alpha_{0}+\alpha_{1} C D L_{i t-1}+\alpha_{2} C D L_{i t-1} * \operatorname{POST}_{i t}+\alpha_{3} \operatorname{SIZE}_{i t}+\alpha_{4} \operatorname{SIZE}_{i t}^{2}+\alpha_{5} L O A N_{i t}+ \\
& \alpha_{6} C_{A P R_{i t}}+\alpha_{7} E B P_{i t}+\alpha_{8} L L P_{i t-1}+\alpha_{9} L I Q U I D_{i t}+\alpha_{10} V_{O L R O A_{i t}}+\alpha_{11} \Delta E B P_{i t+1}+\alpha_{12} P U B L I C_{i t}+ \\
& \alpha_{13} B I G 4_{i t}+B A N K \_S T A T E_{-} Y E A R \_E F F E C T S+\varepsilon_{i t}
\end{aligned}
$$

where $P O S T_{i t}$ is a dummy variable that equals 1 for years 2008-2010, and 0 for years 2005-2007. Our main variable of interest is the interaction term $C D L_{i t-1} * P O S T_{i t}$. We report the results in Table 8 , where we find that the coefficient of the interaction term is negative and statistically significant at the $1 \%$ level ( $t$-value $=-6.06$ and -7.16 , respectively), suggesting that the funding structure focusing on core deposits has a greater impact on earnings quality of banks when retail depositors receive higher FDIC deposit insurance coverage. 
[Table 8]

\subsection{Alternative Model Specification and Measures of Earnings Quality}

Other than the variables used in the baseline regressions, we incorporate several macro-level variables to control for the impact of changes in economic conditions on earnings quality, we re-estimate the baseline models by adding control variables for both change in state GDP $\left(\Delta S T_{-} G D P_{i t}\right)$ and change in state unemployment rate $\left(\Delta S T_{-} U R_{i t}\right)$. Once again, controlling for these macroeconomic variables does not alter our inferences, suggesting that economic conditions do not drive our results. Overall, our untabulated results in this section confirm that the findings from the main regressions are robust to alternative model specifications.

Following the main regressions, we further divide the $D L L P$, based on their signs, into negative and positive discretionary accruals, and test their association with bank funding structure. Negative DLLP is of particular interest because of its income-increasing effect on reported earnings. We use $A B S I I D L L P A_{i t}$ and $A B S I I D L L P \_B_{i t}$ to represent the absolute value of income-increasing DLLP, and $A B S I D D L L P \_A_{i t}$ and $A B S I D D L L P_{-} B_{i t}$ to represent the absolute value of income-decreasing $D L L P$. We report the regression results for the absolute value of income-increasing DLLP in Panel A of Table 9. The coefficient on $C D L_{i t-1}$ is significantly negative ( $t$-value $=-8.54$ and -10.82 , respectively), indicating that banks with more retail funding engage in less income-increasing earnings manipulation. We report results for income-decreasing DLLP in Panel B of Table 9. The coefficient on $C D L_{i t}$ is again significantly negative ( $t$-value $=-9.72$ and -10.87 , respectively), lending extra support to the positive role that retail deposits play in improving bank earnings quality.

Next, we consider alternative measures of earnings quality. ${ }^{13}$ According to the accounting literature, managers in low earnings quality banks are more likely to use their discretion to meet-or-beat

\footnotetext{
${ }^{13}$ We also use the likelihood of equity restatements (RESTATE) through call report item RIADB507 to represent banks' earnings quality. RESTATE is a dummy variable that equals 1 if the item RIADB507 (Restatements due to corrections of 
earnings benchmark (Altamuro and Beatty 2010; Kanagaretnam, Lim and Lobo 2010). Thus, banks with greater reliance on retail deposits are expected to be less likely to meet-or-beat earnings benchmarks. We use a dummy variable of avoiding losses $\left(L S A V_{i t}\right)$ as an indicator of meeting-or-beating earnings benchmark, and estimate the following probit regression model:

$L S A V_{i t}=\alpha_{0}+\alpha_{1} C D L_{i t-1}+\alpha_{2} S I Z E_{i t}+\alpha_{3} \operatorname{SIZE}_{i t}^{2}+\alpha_{4} \operatorname{LOAN}_{i t}+\alpha_{5} C A P R_{i t}+\alpha_{6} E B P_{i t}+$ $\alpha_{7} L L P_{i t-1}+\alpha_{8} L I Q U I D_{i t}+\alpha_{9}$ VOLROA $_{i t}+\alpha_{10} \Delta E B P_{i t+1}+\alpha_{11}$ PUBLIC $_{i t}+\alpha_{12} B I G 4_{i t}+$ BANK_STATE_YEAR_EFFECTS $+\varepsilon_{i t}$

where $L S A V_{i t}$ is a dummy variable that equals 1 if earnings before taxes scaled by beginning total assets is between 0 and 0.001 , and 0 otherwise. ${ }^{14}$ Our primary variable of interest is $C D L_{i t-1}$ in Equation (5). Based on the prediction that retail deposits are associated with lower likelihood of meeting-or-beating earnings benchmarks, we expect the coefficient on $C D L_{i t-1}$ to be significantly negative. Following prior research, we control for bank characteristics, such as bank size $\left(S I Z E_{i t}\right)$, the square of bank size $\left(S I Z E_{i t}^{2}\right)$, bank loans $\left(L O A N_{i t}\right)$, leverage ratio $\left(C A P R_{i t}\right)$, earnings before $L L P\left(E B P_{i t}\right)$, lagged $L L P\left(L L P_{i t-1}\right)$, liquid assets $\left(L I Q U I D_{i t}\right)$, earnings volatility $\left(V O L R O A_{i t}\right)$, future change in $E B P\left(\triangle E B P_{i t+1}\right)$, listing status $\left(P U B L I C_{i t}\right)$, audit quality $\left(B I G 4_{i t}\right)$ as well as bank, state and year fixed effects. Standard errors are clustered at the bank level.

Panel $\mathrm{C}$ of Table 9 reports the probit regression results for our loss avoidance analysis. A negative sign for the coefficient on our primary variable of interest $C D L_{i t-1}$ will indicate that banks with greater reliance on retail deposits funding are less likely to manage earnings to avoid losses. We find a

material accounting errors and changes in accounting principles) is either positive or negative for the bank in year $t$, and 0 otherwise. But one potential caveat with identifying restatements through item RIADB507 is that some banks may have made direct corrections to the original call reports without reporting errors through item RIADB507. Besides, item RIADB507 also records the changes in bank equity capital due to cumulative effect of changes in accounting principles in addition to corrections of material accounting errors. We estimate a probit model by regressing RESTATE $E_{i t}$ on $C D L_{i t-1}$ and control variables, and find a significantly negative coefficient on $C D L_{i t-1}$, indicating that an increase in retail deposits ratio makes banks less likely to restate banks' equity capital accounts.

${ }^{14}$ In our sensitivity tests, we have tried the cut off points $0.002,0.005,0.01$ for the definition of $L S A V_{i t}$. The results remain robust to the different cut off points in defining $L S A V_{i t}$. 
negative association between retail deposits ratio and bank loss avoidance, and the coefficient on $C D L_{i t-1}$ is significantly negative at the $1 \%$ level $(t$-value $=-7.97)$. This result supports our prediction that the stable and information-insensitive retail deposit funding diminishes bank managers' incentives of meeting-or-beating earnings benchmarks. The findings relating to control variables are generally consistent with prior studies (e.g., Altamuro and Beatty 2010; Kanagaretnam et al. 2011; Kanagaretnam et al. 2014; Kanagaretnam et al. 2015).

Finally, prior literature (e.g., Wahlen, 1994; Kanagaretnam et al. 2003; Kanagaretnam et al. 2004) finds that banks use $L L P$ to smooth income. To do so, banks increase $L L P$ when pre-managed earnings are high, and decrease $L L P$ when pre-managed earnings are low. We are interested in determining whether different funding structures increase or decrease banks' propensity to smooth income. We estimate income smoothing as the contemporaneous relationship between $L L P_{i t}$ and $E B P_{i t}$ and the effects of $C D L_{i t-1}$ on income smoothing by including interaction term $E B P_{i t} * C D L_{i t-1}$. Following Kanagaretnam et al. (2011), we include factors that have been identified in prior research to control for non-discretionary component of $L L P$ : bank size $\left(S I Z E_{i t}\right)$, the square of bank size $\left(S I Z E_{i t}^{2}\right)$, bank loans $\left(L O A N_{i t}\right)$, change in loans $\left(\triangle L O A N_{i t}\right)$, lagged $L L P\left(L L P_{i t-1}\right)$, non-performing loans $\left(N P L_{i t}\right)$, change in non-performing loans $\left(\triangle N P L_{i t}\right)$, capital ratio $\left(C A P R_{i t}\right)$, listing status $\left(P U B L I C_{i t}\right)$, audit quality $\left(B I G 4_{i t}\right)$, as well as bank, state and year fixed effects. Standard errors are also clustered at the bank level. Specifically, we estimate the following OLS regression model:

$$
\begin{aligned}
& L L P_{i t}=\alpha_{0}+\alpha_{1} E B P_{i t}+\alpha_{2} C D L_{i t-1}+\alpha_{3} E B P_{i t} * C D L_{i t-1}+\alpha_{4} S I Z E_{i t}+\alpha_{5} S I Z E_{i t}^{2}+\alpha_{6} L O A N_{i t}+ \\
& \alpha_{7} \Delta L O A N_{i t}+\alpha_{8} L L P_{i t-1}+\alpha_{9} N P L_{i t}+\alpha_{10} \Delta N P L_{i t}+\alpha_{11} C A P R_{i t}+\alpha_{12} P U B L I C_{i t}+\alpha_{13} B I G 4_{i t}+ \\
& \text { BANK_STATE_YEAR_EFFECTS }
\end{aligned}
$$

The variables of interest are $E B P_{i t}$, and its interaction with $C D L_{i t-1}$. Consistent with the income smoothing argument, we expect a positive coefficient on $E B P_{i t}$. Besides, if retail funding leads to higher 
earnings quality, we would expect lower income smoothing for banks with high $C D L$. Thus, we would expect a negative coefficient on the interaction term $E B P_{i t} * C D L_{i t-1}$. We report the regression results of the association between retail funding structure and income smoothing in Panel D of Table 9. Consistent with income smoothing argument, $E B P_{i t}$ is positively and significantly associated with $L L P_{i t}$, indicating the prevalence of income smoothing among profitable banks. Furthermore, we find a significantly negative coefficient $(t$-value $=-2.62)$ on the interaction term $E B P_{i t} * C D L_{i t-1}$, indicating that an increase in retail deposits ratio reduces the extent to which bank managers use $L L P$ to manipulate earnings. Overall, these results support our prediction that more retail deposits result in greater earnings quality by moderating banks' incentives to smooth earnings.

[Table 9]

\subsection{Subsample Tests}

In the baseline regression, we focused on the entire period of 20 years, we now investigate the impact of bank funding structure on bank earnings quality in each of the three sub-periods separately: pre-crisis (1993-2006), crisis (2007-2009), and post-crisis (2010-2012). We present the regression results for pre-crisis, crisis, and post-crisis periods in Panels A, B and C of Table 10, respectively. The regression results show a significantly negative association between $C D L_{i t-1}$ and $A B S D L L P_{-} A_{i t}$ and $A B S D L L P_{-} B_{i t}$ across all three sub-periods, suggesting that the impact of bank funding on discretionary accruals management is not driven by specific sample period.

We also provide evidence on whether retail deposit funding helps banks prevent asset deterioration, proxied by large non-performing loans (i.e., $N P L_{i t}>5 \%$ ), during the three subperiods. Untabulated results indicate that $C D L_{i t-1}$ is negatively related to large non-performing loans at the $1 \%$ level during all the three subperiods. Overall, our evidence suggests that banks with higher retail funding 
ratio had a lower incidence of asset deterioration, likely due to the less opportunistic financial reporting and lower risk-taking behaviors.

Next, we investigate whether the positive relationship between funding structure and earnings quality differs across banks with different sizes. We perform this additional test to mitigate the concern that large banks are typically funded with higher levels of wholesale funds and lower levels of retail deposits, and that $C D L$ is a mere indicator of small banks rather than retail deposits per se. Additionally, banks with total assets greater than $\$ 500$ million before 2005 and greater than $\$ 1$ billion after 2005 are subject to FDICIA internal control regulations, but banks with total assets less than $\$ 500$ million before 2005 and less than $\$ 1$ billion after 2005 are free from such regulations. FDICIA internal control regulations require regulated banks to have their financial statements audited, and their CEO and CFO to sign on the management report to provide an assessment of the effectiveness of the internal control structure and procedures (Jin et al. 2013a; Jin et al. 2013b). Thus, FDICIA banks are larger in size and are subject to a more rigorous financial reporting environment. Again, untabulated results attest to a significant and negative association between $C D L_{i t-1}$ and $A B S D L L P_{-} A_{i t}$ and $A B S D L L P_{-} B_{i t}$ across both FDICIA and non-FDICIA banks subsamples as well as among both public and private banks subsamples, suggesting that funding structure influences earnings management regardless of banks' external regulations or listing status.

[Table 10]

\subsection{Path Analysis}

The primary objective of our study is to examine the direct effects of bank funding structure on bank earnings quality. It is possible that the quality of bank earnings could be constrained by bank lending behaviors and loan types. For example, Dagher and Kazimov (2015) find that retail funding is associated with mortgage lending. To the extent that the estimated discretion in $L L P$ is associated with 
mortgage loans, the effects of bank funding structure on bank earnings quality could also be indirect through mortgage lending. To explore this possibility, we follow the methodology in Bhattacharya et al. (2012) and employ path analysis to decompose the relation between the source variable (bank funding structure) and the outcome variable (bank earnings quality) into the direct path and the indirect path through mortgage lending. Following Frame et al. (2012), residential mortgages (MORT $i t)$ include (i) the amount of all permanent loans secured by first liens on 1-to-4 family residential properties, (ii) the amount of all permanent loans secured by junior (i.e., other than first) liens on 1-to-4 family residential properties, and (iii) the amount of outstanding home equity lines.

The results of the path analysis are presented in Figure 1, which shows the standardized path estimates, along with the significance of each of the path estimates. The path estimates of $C D L_{i t-1}$ to ABSDLLP_ $A_{i t}$ and $A B S D L L P_{-} B_{i t}$ attributable to the direct path are -0.101 and -0.086 respectively. The direct (i.e., unmediated) effects of $C D L_{i t-1}$ on $A B S D L L P_{-} A_{i t}$ and $A B S D L L P B_{i t}$ are statistically significant at the $1 \%$ level, indicating that retail deposits are significantly and negatively associated with discretionary $L L P$. Meanwhile, the effects of $C D L_{i t-1}$ on $A B S D L L P_{-} A_{i t}$ and $A B S D L L P \_B_{i t}$ can also be attributable to an indirect path through the mediating variable $M O R T_{i t}$. The path estimate of $C D L_{i t-1}$ on $M O R T_{i t}$ is $0.088(0.095)$, suggesting that residential mortgages are funded by retail deposits. The path estimates of $M O R T_{i t}$ on $A B S D L L P_{-} A_{i t}$ and $A B S D L L P_{-} B_{i t}$ are -0.064 and -0.082 , each significant at the $1 \%$ level, implying that residential mortgages are negatively associated with discretion in $L L P$, and thus positively associated with bank earnings quality. Taken together, the indirect (i.e., mediated) effects of $C D L_{i t-1}$ on $A B S D L L P_{-} A_{i t}$ and $A B S D L L P_{-} B_{i t}$ are -0.006 and $-0.008 .{ }^{15}$ Overall, our results indicate that funding structure has a significant and direct effect on bank earnings quality and that this direct effect of

\footnotetext{
${ }^{15}$ The indirect effect of $C D L_{i t-1}$ on $A B S D L L P_{-} A_{i t}=0.088^{*}(-0.064)=-0.006$; and the indirect effect of $C D L_{i t-1}$ on ABSDLLP_ $B_{i t}=0.095 *(-0.082)=-0.008$.
} 
funding structure on bank earnings quality is considerably larger than the indirect effect of funding structure on bank earnings quality through mortgage lending.

[Figure 1]

\section{Conclusions}

In recent years, the banking sector has seen a rapid change in the funding structure: banks increasingly borrow more from the wholesale market to supplement their traditional retail deposits. This major change in the banking sector has interesting implications for the new bank funding model. In this study, we examine one important implication, that is, how bank funding structure influences banks' earnings quality.

Our empirical results indicate that greater reliance on retail deposits over wholesale funds increases the earnings quality of banks, as more retail deposits are associated with smaller magnitude of earnings management through discretionary $L L P$. This finding holds in all three sub-periods (i.e., precrisis, crisis, and post-crisis), across both small and large banks that receive different intensity of FDICIA internal control regulations, and across both public and private banks subsamples. Meanwhile, higher retail deposit ratio also moderates the likelihood of meeting-or-beating earnings benchmark in the form of loss avoidance, and the propensity of income smoothing through LLP. Overall, our findings indicate that banks' earnings quality improves with the share of retail deposits in bank liability structure.

We offer the following explanations for our findings. First, compared with wholesale funds, retail deposits are more stable and reliable for banks. Thus, banks relying more on the share of retail deposits may have greater ability of rolling over the funds to generate expected earnings and cash flows. In addition, retail funding reflects a conservative business model, leading to less earnings volatility and lower income smoothing. Second, retail deposits are less sensitive to banks' accounting information and economic policies than wholesale funds. To the extent that some of the retail depositors are relationship 
lenders, they are better at assessing bank risk via private channels than via financial statements. Thus, bank managers may have fewer incentives to manipulate external financial reports (i.e., income statement) to attract retail deposits. Third, unlike some categories of wholesale funds, retail deposits do not entail covenant restrictions, diminishing bank managers' incentives to engage in earnings or capital management to avoid covenant violations. Finally, banks with higher proportion of retail deposits have higher insurance risk for FDIC, thus FDIC will exercise higher scrutiny over those banks' financial information.

Our primary contribution is that bank funding structure has a significant impact on banks' earnings quality, with retail deposits improving it and wholesale funds decreasing it. This study enhances our understanding about the roles of different suppliers of bank funds in influencing quality of bank accounting information. Our evidence seems to contradict the bright side of wholesale funding advocated by prior literature which posits that sophisticated wholesale financiers impose market discipline (Calomiris and Kahn 1991). In contrast, our findings are more consistent with the argument that retail deposits add to bank funding stability and reduce banks' opportunistic behaviors. In addition, by examining the earnings quality impact for all banks with various funding structures, our study provides timely evidence to assess how the shift from traditional retail deposit funding model to the recent wholesale market funding model influences the financial reporting quality for the banking sector as a whole. This is particularly salient, given that our evidence points to the potential deterioration of banks' earnings quality associated with reliance on wholesale funding. In this regard, we believe that our study provides valuable information to bank regulators and encourages them to monitor and regulate banks with rapid and excessive growth in their wholesale funding. 


\section{References}

Ackermann, J., 2008. The subprime crisis and its consequences. Journal of Financial Stability 4 (4), 329-337.

Ahmed, A., Thomas, S., Takeda, C., 1999. Bank loan loss provisions: a reexamination of capital management, earnings management and signaling effects. Journal of Accounting and Economics 28 (1), $1-26$.

Allen, L., DeLong, G., Saunders, A., 2004. Issues in the credit risk modeling of retail markets. Journal of Banking and Finance 28 (4), 727-752.

Altamuro, J., Beatty. A., 2010. How does internal control regulation affect financial reporting? Journal of Accounting and Economics 49 (1-2), 58-74.

Amato, L.H., Amato, C.H., 2007. The effects of firm size and industry on corporate giving. Journal of Business Ethics 72, 229-241.

Amato, L.H., Amato, C.H., 2012. Retail philanthropy: Firm size, industry, and business cycle. Journal of Business Ethics 107, 435-448.

Beatty, A., Harris, D. 1999. The effects of taxes, agency costs and information asymmetry on earnings management: A comparison of public and private firms. The Review of Accounting Studies 4 (3\&4), 299-326.

Bertschek, I., Entorf, H., 1996. One nonparametric estimation of the Schumpeterian link between innovation and firm Size: Evidence from Belgium, France, and Germany. Empirical Economics 21, 401426.

Bichsel, R., Spielmann, C., 2004. State-owned banks as competition enhancers, or the grand illusion. Working Paper, Swiss National Bank.

Basel Committee on Banking Supervision (BCBS), 2011. Global systemically important banks: assessment methodology and the additional loss absorbency requirement. http://www.bis.org/publ/bcbs207.htm.

Beatty, A., Liao, S., 2011. Do delays in expected loss recognition affect banks' willingness to lend? Journal of Accounting and Economics 52 (1), 1-20.

Beatty, A., Liao, S., 2014. Financial accounting in the banking industry: a review of the empirical literature. Journal of Accounting and Economics 58 (2-3), 339-383.

Beaver, W., Eger, C., Ryan, S., Wolfson, M., 1989. Financial reporting, supplemental disclosures, and bank share prices. Journal of Accounting Research. 27 (2), 157-178. 
Bennett, R.L., Hwa, V., Kwast, M.L., 2015. Market discipline by bank creditors during the 2008-2010 crisis. Journal of Financial Stability 20, 51-69.

Berger, A. N., Turk-Ariss. R., 2015. Do depositors discipline banks and did government actions during the recent crisis reduce this discipline? An international perspective. Journal of Financial Services Research 48 (2), 103-126.

Bhattacharya, N., Ecker, F., Olsson, P., Schipper, K., 2012. Direct and mediated associations among earnings quality, information asymmetry, and the cost of equity. The Accounting Review 87 (2), 449-282.

Boot, A., Ratnovski, L., 2016. Banking and trading. Review of Finance 20 (6), 2219-2246.

Bushman, R., 2014. Thoughts on financial accounting and the banking industry. Journal of Accounting and Economics 58 (2-3), 384-395.

Bushman, R.M., Williams, C.D., 2012. Accounting discretion, loan loss provisioning, and discipline of banks' risk-taking. Journal of Accounting and Economics 54 (1), 1-18.

Billett, M.T., Garfinkel J.A., 2004. Financial flexibility and the cost of external finance for U.S. banks. Journal of Money, Credit and Banking 36 (5), 827-852.

Calomiris, C., 1999. Building an incentive-compatible safety net. Journal of Banking and Finance 23 (10), 1499-1519.

Calomiris, C., Kahn, C., 1991. The role of demandable debt in structuring optimal banking arrangements. American Economic Review 81 (3), 497-513.

Calomiris, C., Wilson, B., 2004. Bank capital and portfolio management: the 1930s "Capital Crunch" and the scramble to shed risk. Journal of Business 77 (3), 421-455.

Cheng, Q., Warfield, T., Ye, M., 2011. Equity Incentives and Earnings Management: Evidence from the Banking Industry. Journal of Accounting, Auditing \& Finance 26 (2): 317-349.

Cohen, L.J., Cornett, M.M., Marcus, A.J., Tehranian, H., 2014. Bank earnings management and tail risk during the financial crisis. Journal of Money, Credit, and Banking 46 (1), 171-197.

Collins, J.H., Shackelford, D.A., J.M. Wahlen., 1995. Bank Differences in the Coordination of Regulatory Capital, Earnings, and Taxes. Journal of Accounting Research 33 (2), 263-291.

Craig, B., Dinger, V., 2013. Deposit market competition, wholesale funding, and bank risk. Journal of Banking and Finance 37 (9), 3605-3622.

Dagher, J., Kazimov, K., 2015. Banks' liability structures and mortgage lending during the financial crisis. Journal of Financial Economics 116 (3), 565-582. 
Davenport, A.M., McDill, K.M., 2006. The depositor behind the discipline: A micro-level case study of Hamilton Bank. Journal of Financial Services Research 30, 93-109.

Dechow, P., Dichev, I., 2002. The quality of accruals and earnings: the role of accrual estimation errors. The Accounting Review 77 (Supplement), 35-59.

Dechow, P., Ge, W., Schrand, C., 2010. Understanding earnings quality: a review of the proxies, their determinants and their consequences. Journal of Accounting and Economics 50 (2-3), 344-401.

DeFond, M.L., Lim, C.Y., Zang, Y., 2016. Client conservatism and auditor-client contracting. The Accounting Review 91 (1), 69-98.

Demirguç-Kunt, A., Detragiache, E., 2002. Does deposit insurance increase banking system stability? An empirical investigation. Journal of Monetary Economics 49 (7), 1373-1406.

Demirguc-Kunt, A., Huizinga, H., 2004. Market discipline and deposit insurance. Journal of Monetary Economics 51 (2), 375-399.

Demirguc-Kunt, A., Huizinga, H., 2010. Bank activity and funding strategies: the impact on risk and returns. Journal of Financial Economics 98 (3), 626-650.

Dinger, V., Craig, B., 2014. Volatile lending and bank wholesale funding. Federal Reserve Bank of Cleveland.

Farrell, K., Unlu, E., Yu, J., 2014. Stock repurchases as an earnings management mechanism: the impact of financing constraints. Journal of Corporate Finance 25, 1-15.

Federal Deposit Insurance Corporation (FDIC), 2015. Deposit Insurance FAQs. https://www.fdic.gov/deposit/deposits/faq.html.

Federal Deposit Insurance Corporation (FDIC), 2016. Risk-Based Assessment System. https:/www.fdic.gov/deposit/insurance/risk/.

Flannery, M., 1982. Retail bank deposits as quasi-fixed factors of production. American Economic Review 72 (3), 527-536.

Forti, C., Schiozer, R.F., 2015. Bank dividends and signaling to information-sensitive depositors. Journal of Banking and Finance 56, 1-11.

Frame, W.S., Hancock, D., Passmore, W., 2012. Federal home loan bank advances and commercial bank portfolio composition. Journal of Money, Credit and Banking 44 (4), 661-684.

Gallemore, J., 2013. Does bank opacity enable regulatory forbearance? Working paper, Chicago Booth.

Gatev, E., Strahan, P., 2006. Banks' advantage in hedging liquidity risk: theory and evidence from the commercial paper market. Journal of Finance 61 (2), 867-892. 
Gorton, G., Metrick, M., 2012. Securitized banking and the run on repo. Journal of Financial Economics 104 (3), 425-451.

Goyal, V.K., 2005. Market discipline of bank risk: evidence from subordinated debt contracts. Journal of Financial Intermediation 14 (3), 318-350.

Harijoto, M.A., Jo, H., 2011. Corporate governance and CSR nexus. Journal of Business Ethics 100 (1), 45-67.

Hausman, J.A., 1978. Specification tests in econometrics. Econometrica 46 (6), 1251-1271.

Homanen, M., 2018. Depositors disciplining banks: The impact of scandals. Working paper, City University of London.

Hirtle, B.J., Stiroh, K.J., 2007. The return to retail and the performance of US banks. Journal of Banking and Finance 31 (4), 1101-1133.

Huang, R., Ratnovski, L., 2011. The dark side of bank wholesale funding. Journal of Financial Intermediation 20 (2), 248-263.

Huizanga, H., Laeven, L., 2012. Bank valuation and accounting discretion during a financial crisis. Journal of Financial Economics 106 (3), 614-663

Ivashina, V., Scharfstein, D., 2010. Bank lending during the financial crisis of 2008. Journal of Financial Economics 97 (3), 319-338.

Iyer, R., Puri, M., Ryan, N., 2016. A tale of two runs: Depositor responses to bank solvency risk. The Journal of Finance 71 (6), 2687-726.

Jayaratne, J., Strahan, P.E., 1998. Entry restrictions, industry evolution, and dynamic efficiency: evidence from commercial banking. Journal of Law and Economics 41 (1), 239-273.

Jiang, L., Levine, R., Lin., C., 2016. Competition and bank opacity. Review of Financial Studies 29 (7), 1911-1942.

Jin, J.Y., Kanagaretnam, K., Lobo, G.J., 2013a. Unintended consequences of the increased asset threshold for FDICIA internal controls: evidence from US private banks. Journal of Banking and Finance 37 (12), 4879-4892.

Jin, J.Y., Kanagaretnam, K., Lobo, G.J., Mathieu, R., 2013b. Impact of FDICIA internal controls on bank risk taking. Journal of Banking and Finance 37 (2), 614-624.

Kanagaretnam, K., Krishnan, G., Lobo, G.J., 2010. An empirical analysis of auditor independence in the banking industry. The Accounting Review 85 (6), 2011-2046. 
Kanagaretnam, K., Lim, C.Y., Lobo, G.J., 2010. Auditor reputation and earnings management: international evidence from the banking industry. Journal of Banking and Finance 34 (10), 2318-2327.

Kanagaretnam, K., Lim, C.Y., Lobo, G.J., 2011. Effects of national culture on earnings quality of banks. Journal of International Business Studies 42 (6), 853-874.

Kanagaretnam, K., Lim, C.Y., Lobo, G.J., 2014. Effects of international institutional factors on earnings quality of banks. Journal of Banking and Finance 39, 87-106.

Kanagaretnam, K., Lobo, G., Mathieu, R., 2003. Managerial incentives for income smoothing through bank loan loss provisions. Review of Quantitative Finance and Accounting 20 (1), 63-80.

Kanagaretnam, K., Lobo, G., Wang, C., 2015. Religiosity and earnings management: international evidence from the banking industry. Journal of Business Ethics 132 (2), 277-296.

Kanagaretnam, K., Lobo, G., Yang, D., 2004. Joint tests of signaling and income smoothing through bank loan loss provisions. Contemporary Accounting Research 21 (4), 843-884.

Kim, M., Kliger, D., Vale, B., 2003. Estimating switching costs: the case of banking. Journal of Financial Intermediation 12 (1), 25-56.

Kim, M., Kross, W., 1998. The impact of the 1989 change in bank capital standards on loan loss provisions and loan write-offs. Journal of Accounting and Economics 25 (1), 69-99.

Kohler, M., 2015. Which banks are more risky? the impact of business models on bank stability. Journal of Financial Stability 16, 195-212.

Lambert, C., Noth, F., Schüwer. U., 2017. How do insured deposits affect bank risk? Evidence from the 2008 Emergency Economic Stabilization Act. Journal of Financial Intermediation 29, 81-102.

Lim, I., Hagendorff, J., Armitage, S., 2016. Regulatory monitoring, information asymmetry and Earnings Quality: evidence from the banking industry, Working paper, University of Edinburgh Business School.

Loutskina, E., Strahan, P.E., 2011. Informed and uninformed investment in housing: the downside of diversification. Review of Financial Studies 24 (5), 1447-1480.

Macey, J.R., Miller, G.P., 1988. Bank failures, risk monitoring and the market for bank control. Columbia Law Review 88 (6), 1153-1226.

Martinez Peria, M.S., Schmukler, S.L., 2001. Do depositors punish banks for bad behavior? Market discipline, deposit insurance, and banking crises. Journal of Finance 56 (3), 1029-1051.

Puri, M., Rocholl, J., 2008. On the importance of retail banking relationships. Journal of Financial Economics 89 (2), 253-267. 
Siggelknow, N., 2003. Why focus? A study of intra-industry focus effects. Journal of Industrial Economics 51, 121-150.

Sharpe, S.A., 1997. The effect of consumer switching costs on prices: a theory and its application to the bank deposit market. Review of Industrial Organization 12 (1), 79-94.

Shin, H.S., 2009. Reflections on Northern Rock: the bank run that heralded the global financial crisis. Journal of Economic Perspectives 23 (1), 101-119.

Song, F., Thakor, A.V., 2007. Relationship banking, fragility, and the asset-liability matching problem. Review of Financial Studies 20 (6), 2129-2177.

Van den End, J., Tabbae, M., 2012. When liquidity risk becomes a systemic issue: empirical evidence of bank behavior. Journal of Financial Stability 8 (2), 107-120.

Wahlen, J.M. 1994. The nature of information in commercial bank loan loss disclosures. The Accounting Review 69 (3), 455-478. 


\section{Appendix}

\begin{tabular}{|c|c|}
\hline Dependent Variables & \\
\hline$A B S D L L P A_{-} A_{i t}$ & $\begin{array}{l}\text { The absolute value of discretionary loan loss provisions in year } t \text {, calculated as the absolute } \\
\text { value of the residuals from the OLS regression of Equation (1a). }\end{array}$ \\
\hline$A B S D L L P_{-} B_{i t}$ & $\begin{array}{l}\text { The absolute value of discretionary loan loss provisions in year } t \text {, calculated as the absolute } \\
\text { value of the residuals from the OLS regression of Equation (1b). }\end{array}$ \\
\hline ABSIIDLLP_A $A_{i t}$ & $\begin{array}{l}\text { The absolute value of income-increasing discretionary loan loss provisions in year } t \text {, } \\
\text { calculated as the absolute value of the negative residuals from the OLS regression of } \\
\text { Equation (1a). }\end{array}$ \\
\hline$A B S I I D L L P_{-} B_{i t}$ & $\begin{array}{l}\text { The absolute value of income-increasing discretionary loan loss provisions in year } t \text {, } \\
\text { calculated as the absolute value of the negative residuals from the OLS regression of } \\
\text { Equation (1b). }\end{array}$ \\
\hline ABSIDDLLP_A $A_{i t}$ & $\begin{array}{l}\text { The absolute value of income-decreasing discretionary loan loss provisions in year } t \text {, } \\
\text { calculated as the absolute value of the negative residuals from the OLS regression of } \\
\text { Equation (1a). }\end{array}$ \\
\hline$A B S I D D L L P P_{i} B_{i t}$ & $\begin{array}{l}\text { The absolute value of income-decreasing discretionary loan loss provisions in year } t \text {, } \\
\text { calculated as the absolute value of the negative residuals from the OLS regression of } \\
\text { Equation (1b). }\end{array}$ \\
\hline$L S A V_{i t}$ & $\begin{array}{l}\text { A dummy variable that equals } 1 \text { if earnings before taxes during year } t \text { scaled by beginning } \\
\text { total assets is in the interval between } 0 \text { and } 0.001 \text {, and } 0 \text { otherwise. }\end{array}$ \\
\hline \multicolumn{2}{|c|}{ Main Variable of Interest } \\
\hline$C D L_{i t-1}$ & Core deposits (or called retail deposits) scaled by total liabilities in year $t-1$. \\
\hline \multicolumn{2}{|l|}{$\begin{array}{l}\text { Other Bank-Level } \\
\text { Variables }\end{array}$} \\
\hline$S I Z E_{i t}$ & Natural logarithm of total assets in year $t$. \\
\hline $\operatorname{LOAN}_{i t}$ & Total loans scaled by total deposits in year $t$. \\
\hline$C A P R_{i t}$ & Total liabilities scaled by total equity in year $t$. \\
\hline$E B P_{i t}$ & Earnings before loan loss provisions during year $t$ scaled by beginning total assets. \\
\hline$L L P_{i t}$ & Loan loss provisions scaled by total assets in year $t$. \\
\hline$L I Q U I D_{i t}$ & Liquid assets scaled by total assets in year $t$. \\
\hline$V_{O L R O A}$ & Standard deviation of net income scaled by total assets in year $t$. \\
\hline$\Delta E B P_{i t}$ & Change in $E B P$ in year $t$ \\
\hline PUBLIC $i t$ & A dummy variable that equals 1 for a public bank, and 0 otherwise. \\
\hline$B I G 4_{i t}$ & A dummy variable that equals 1 if the bank is audited by a big 4 auditor, and 0 otherwise. \\
\hline$C L_{i t}$ & Commercial and industrial loans scaled by total loans in year $t$. \\
\hline$R L_{i t}$ & Real estate loans scaled by total loans in year $t$ \\
\hline$I L_{i t}$ & Individual loans scaled by total loans in year $t$. \\
\hline$A L_{i t}$ & Agriculture loans scaled by total loans in year $t$ \\
\hline$D L_{i t}$ & Loans to depository institutions scaled by total loans in year $t$. \\
\hline$C O_{i t}$ & Loan charge-offs scaled by total loans in year $t$. \\
\hline$N P L_{i t}$ & Non-performing loans scaled by total loans in year $t$ \\
\hline$\triangle N P L_{i t}$ & Change in non-performing loans during year $t$ scaled by beginning total loans. \\
\hline$\triangle L O A N_{i t}$ & Change in loans during year $t$ scaled by beginning total assets. \\
\hline$L L A_{i t}$ & Loan loss allowance scaled by total loans in year $t$. \\
\hline$A G E_{i t}$ & Natural logarithm of 1 plus the number of years since the bank became active. \\
\hline$M O R T_{i t}$ & $\begin{array}{l}\text { Residential mortgages scaled by total assets in year } t \text {. Residential mortgages include the } \\
\text { amount of all permanent loans secured by first liens on 1-to- } 4 \text { family residential properties, } \\
\text { the amount of all permanent loans secured by junior (i.e., other than first) liens on 1-to- } 4\end{array}$ \\
\hline
\end{tabular}




\begin{tabular}{l|l}
\hline \hline & family residential properties, and the amount of outstanding home equity lines. \\
\hline Macro-Level Variables & \\
\hline$P O S T_{i t}$ & A dummy variable that equals 1 for years 2008-2010, and 0 for years 2005-2007. \\
\hline$\Delta S T_{-} G D P_{i t}$ & Change in GDP of the state of the bank' headquarter during year $t$. \\
\hline$\Delta S T_{-} H P I_{i t}$ & $\begin{array}{l}\text { Change in the return of the house price index of the state of the bank' headquarter during } \\
\text { year } t .\end{array}$ \\
\hline$\Delta S T_{-} U R_{i t}$ & Change in unemployment rate of the state of the bank' headquarter during year $t$. \\
\hline \hline
\end{tabular}


Table 1 Descriptive Statistics

\begin{tabular}{|c|c|c|c|c|c|c|}
\hline & $\mathrm{N}$ & Mean & Median & Q1 & Q3 & Std. Dev. \\
\hline$A B S D L L P \_A_{i t}$ & 146,343 & 0.002 & 0.001 & 0.000 & 0.002 & 0.002 \\
\hline$A B S D L L P \_B_{i t}$ & 146,343 & 0.001 & 0.001 & 0.000 & 0.001 & 0.002 \\
\hline ABSIIDLLP_A $A_{i t}$ & 100,463 & 0.001 & 0.001 & 0.001 & 0.002 & 0.001 \\
\hline$A B S I I D L L P \_B_{i t}$ & 81,504 & 0.001 & 0.001 & 0.000 & 0.001 & 0.001 \\
\hline ABSIDDLLP_A $A_{i t}$ & 45,880 & 0.003 & 0.001 & 0.000 & 0.003 & 0.004 \\
\hline$A B S I D D L L P \_B_{i t}$ & 64,839 & 0.001 & 0.001 & 0.000 & 0.001 & 0.002 \\
\hline$L S A V_{i t}$ & 146,343 & 0.063 & 0.000 & 0.000 & 0.000 & 0.243 \\
\hline$C D L_{i t-1}$ & 146,343 & 0.812 & 0.832 & 0.748 & 0.897 & 0.112 \\
\hline$S I Z E_{i t}$ & 146,343 & 11.529 & 11.434 & 10.699 & 12.244 & 1.184 \\
\hline$L^{2 O A N} N_{i t}$ & 146,343 & 0.729 & 0.736 & 0.606 & 0.857 & 0.197 \\
\hline$C A P R_{i t}$ & 146,343 & 0.896 & 0.904 & 0.883 & 0.918 & 0.033 \\
\hline$E B P_{i t}$ & 146,343 & 0.006 & 0.005 & 0.003 & 0.007 & 0.005 \\
\hline$L L P_{i t-1}$ & 146,343 & 0.002 & 0.001 & 0.000 & 0.002 & 0.003 \\
\hline$L_{L I Q U I D_{i t}}$ & 146,343 & 0.058 & 0.043 & 0.030 & 0.066 & 0.048 \\
\hline VOLROA $_{i t}$ & 146,343 & 0.010 & 0.002 & 0.001 & 0.003 & 0.651 \\
\hline$\Delta E B P_{i t+1}$ & 146,343 & 0.000 & 0.000 & -0.001 & 0.001 & 0.005 \\
\hline PUBLIC & 146,343 & 0.023 & 0.000 & 0.000 & 0.000 & 0.149 \\
\hline$B I G 4_{i t}$ & 146,343 & 0.015 & 0.000 & 0.000 & 0.000 & 0.123 \\
\hline
\end{tabular}

Table 1 provides the descriptive statistics for all variables used in the analysis. Continuous variables are winsorized at top and bottom 1\%. Definitions of the variables are provided in Appendix. 
Table 2 Pearson Correlation Matrix

Panel A: Pearson Correlation between Variables Used in the Regressions

\begin{tabular}{|c|c|c|c|c|c|c|c|c|c|c|c|c|}
\hline & & 8 & 9 & 10 & 11 & 12 & 13 & 14 & 15 & 16 & 17 & 18 \\
\hline 1 & ABSDLLP_A $A_{i t}$ & -0.138 & 0.033 & 0.042 & -0.046 & 0.071 & 0.287 & 0.075 & 0.007 & -0.104 & -0.009 & 0.016 \\
\hline 2 & $A B S D L L P \_B_{i t}$ & -0.107 & -0.012 & 0.005 & -0.043 & 0.026 & 0.264 & 0.072 & 0.011 & -0.078 & -0.014 & 0.008 \\
\hline 3 & ABSIIDLLP_A $A_{i t}$ & -0.141 & 0.062 & 0.008 & -0.087 & -0.068 & 0.125 & 0.115 & -0.002 & 0.027 & -0.003 & 0.028 \\
\hline 4 & $A B S I I D L L P \_B_{i t}$ & -0.068 & -0.033 & -0.048 & -0.056 & -0.045 & 0.217 & 0.086 & 0.002 & -0.005 & -0.021 & 0.008 \\
\hline 5 & ABSIDDLLP_A $A_{i t}$ & -0.169 & 0.028 & 0.062 & -0.042 & 0.118 & 0.321 & 0.088 & 0.013 & -0.151 & -0.017 & 0.008 \\
\hline 6 & $A B S I D D L L P \_B_{i t}$ & -0.147 & 0.012 & 0.059 & -0.031 & 0.074 & 0.298 & 0.060 & 0.016 & -0.134 & -0.007 & 0.011 \\
\hline 7 & $L S A V_{i t}$ & -0.028 & -0.073 & -0.029 & -0.013 & -0.148 & 0.035 & 0.061 & 0.000 & 0.041 & -0.011 & -0.011 \\
\hline 8 & $C D L_{i t-1}$ & 1.000 & -0.370 & -0.397 & -0.018 & 0.014 & -0.158 & 0.074 & -0.011 & 0.010 & -0.083 & -0.094 \\
\hline 9 & $S I Z E_{i t}$ & & 1.000 & 0.324 & 0.146 & 0.131 & 0.091 & -0.164 & 0.010 & -0.034 & 0.233 & 0.221 \\
\hline 10 & $L O A N_{i t}$ & & & 1.000 & 0.103 & -0.126 & 0.077 & -0.208 & 0.014 & -0.029 & 0.096 & 0.071 \\
\hline 11 & $C A P R_{i t}$ & & & & 1.000 & -0.104 & -0.004 & -0.044 & 0.007 & 0.012 & 0.033 & -0.009 \\
\hline 12 & $E B P_{i t}$ & & & & & 1.000 & -0.015 & -0.084 & 0.002 & -0.453 & -0.009 & 0.012 \\
\hline 13 & $L L P_{i t-1}$ & & & & & & 1.000 & 0.068 & 0.010 & -0.002 & 0.008 & 0.020 \\
\hline 14 & $L I Q U I D_{i t}$ & & & & & & & 1.000 & -0.001 & 0.027 & -0.039 & -0.019 \\
\hline 15 & $V O L R O A_{i t}$ & & & & & & & & 1.000 & 0.000 & -0.002 & 0.000 \\
\hline 16 & $\Delta E B P_{i t+1}$ & & & & & & & & & 1.000 & -0.004 & -0.003 \\
\hline 17 & $P U B L I C_{i t}$ & & & & & & & & & & 1.000 & 0.113 \\
\hline 18 & $B I G 4_{i t}$ & & & & & & & & & & & 1.000 \\
\hline
\end{tabular}

Panel B: Pearson Correlation between Time Series of Core Deposits and Wholesale Funds

\begin{tabular}{|c|c|c|c|c|c|c|c|}
\hline & & 2 & 3 & 4 & 6 & 7 & 8 \\
\hline 1 & $C D_{i t+1}$ & 0.966 & 0.906 & 0.838 & & & \\
\hline 2 & $C D_{i t}$ & 1.000 & 0.952 & 0.879 & & & \\
\hline 3 & $C D_{i t-1}$ & & 1.000 & 0.942 & & & \\
\hline 4 & $C D_{i t-2}$ & & & 1.000 & & & \\
\hline 5 & $W F_{i t+1}$ & & & & 0.937 & 0.842 & 0.751 \\
\hline 6 & $W F_{i t}$ & & & & 1.000 & 0.931 & 0.829 \\
\hline 7 & $W F_{i t-1}$ & & & & & 1.000 & 0.924 \\
\hline 8 & $W F_{i t-2}$ & & & & & & 1.000 \\
\hline
\end{tabular}

Table 2 provides the Pearson correlation Matrix. Panel A provides the Pearson correlation for variables used in the regressions. Panel B provides the Pearson correlation for time series of core deposits (unscaled) and wholesale funds (unscaled). Continuous variables are winsorized at top and bottom $1 \%$. Bold numbers are significant at the 5\% level, based on a two-tailed test. Definitions of the variables are provided in Appendix. 


\section{Table 3 Univariate Tests}

\begin{tabular}{l|c|c|c|c}
\hline \hline & $\begin{array}{c}\text { Low } C D L \\
\text { Bank-Years }\end{array}$ & $\begin{array}{c}\text { High } C D L \\
\text { Bank-Years }\end{array}$ & Difference & $\begin{array}{c}\text { Test of Difference } \\
\text { (t-Statistic) }\end{array}$ \\
\hline Mean $A B S D L L P \_A_{i t}$ & 0.0018 & 0.0014 & 0.0004 & $33.77^{* * *}$ \\
\hline Mean $A B S D L L P \_B_{i t}$ & 0.0013 & 0.0010 & 0.0003 & $27.03^{* * *}$ \\
\hline Mean $A B S I I D L L P_{2} A_{i t}$ & 0.0013 & 0.0011 & 0.0002 & $31.86^{* * *}$ \\
\hline Mean $A B S I I D L L P \_B_{i t}$ & 0.0011 & 0.0010 & 0.0002 & $13.01^{* * *}$ \\
\hline Mean $A B S I D D L L P \_A_{i t}$ & 0.0030 & 0.0021 & 0.0009 & $23.01^{* * *}$ \\
\hline Mean $A B S I D D L L P \_B_{i t}$ & 0.0014 & 0.0011 & 0.0003 & $25.19^{* * *}$ \\
\hline Mean $L S A V_{i t}$ & 0.0693 & 0.0563 & 0.0130 & $10.24^{* * *}$ \\
\hline \hline
\end{tabular}

Table 3 compares the differences in the mean values of earnings quality measures between banks with low $C D L$ and those with high $C D L$. Continuous variables are winsorized at top and bottom $1 \%{ }^{*}, * *, * * *$ denote significance at the $10 \%, 5 \%$, and $1 \%$ levels, respectively, based on a two-tailed test. Definitions of the variables are provided in Appendix. 
Table 4 Estimation of Discretionary Loan Loss Provisions (DLLP)

Panel A: Estimation of DLLP Using Equation (1a)

\begin{tabular}{|c|c|c|}
\hline & \multicolumn{2}{|c|}{$\begin{array}{c}\text { Dependent Variable }=L L P_{i t} \\
(1)\end{array}$} \\
\hline Variable & Coefficient & $\mathrm{t}$-Statistic \\
\hline Intercept & 0.0004 & $1.67 *$ \\
\hline$\Delta N P L_{i t+1}$ & 0.004 & $3.26 * *$ \\
\hline$\triangle N P L_{i t}$ & 0.049 & $36.54 * * *$ \\
\hline$\Delta N P L_{i t-1}$ & 0.044 & $38.75 * * *$ \\
\hline$\Delta N P L_{i t-2}$ & 0.031 & $33.25 * * *$ \\
\hline$S I Z E_{i t-1}$ & 0.0001 & $4.21 * * *$ \\
\hline$\Delta L O A N_{i t}$ & 0.002 & $21.48 * * *$ \\
\hline$\Delta S T_{-} G D P_{i t}$ & -0.00003 & $-6.06 * * *$ \\
\hline$\Delta S T_{-} H P I_{i t}$ & -0.00002 & $-18.93 * * *$ \\
\hline$\Delta S T_{-} U R_{i t}$ & 0.0001 & $4.07 * * *$ \\
\hline State \& Year Fixed Effects & Yes & \\
\hline $\mathrm{N}$ & 148,803 & \\
\hline Adj. $R^{2}$ & 0.171 & \\
\hline
\end{tabular}

Panel B: Estimation of DLLP Using Equation (1b)

\begin{tabular}{l|c|c}
\hline \hline & \multicolumn{2}{|c}{$\begin{array}{c}\text { Dependent Variable }=L L P_{i t} \\
(1)\end{array}$} \\
\hline Variable & Coefficient & t-Statistic \\
\hline Intercept & 0.0002 & 1.36 \\
\hline$L O A N_{i t}$ & 0.001 & $31.31^{* * *}$ \\
\hline$\Delta L O A N_{i t}$ & 0.002 & $-14.81^{* * *}$ \\
\hline$L L A_{i t-1}$ & -0.022 & $122.23^{* * *}$ \\
\hline$C O_{i t}$ & 0.776 & $22.22^{* * *}$ \\
\hline$N P L_{i t-1}$ & 0.020 & $28.01^{* * *}$ \\
\hline$\Delta N P L_{i t}$ & 0.036 & $-5.18^{* * *}$ \\
\hline$C L_{i t}$ & -0.001 & $-9.86^{* * *}$ \\
\hline$R L_{i t}$ & -0.001 & -0.36 \\
\hline$I L_{i t}$ & -0.0001 & $-9.31^{* * *}$ \\
\hline$A L_{i t}$ & -0.001 & $-5.12^{* * *}$ \\
\hline$D L_{i t}$ & -0.012 & \\
\hline State \& Year Fixed Effects & Yes & \\
\hline $\mathrm{N}$ & & \\
\hline Adj. $R^{2}$ & 166,900 & \\
\hline \hline
\end{tabular}

Table 4 provides the OLS regression results of estimating DLLP, with Panel A using Equation (1a) and Panel B using Equation (1b), respectively. Continuous variables are winsorized at top and bottom $1 \% . *, * *, * * *$ denote significance at the $10 \%, 5 \%$, and $1 \%$ levels, respectively, based on a two-tailed test. Standard errors are clustered at the bank level. Definitions of the variables are provided in Appendix. 
Table 5 Earnings Quality and Bank Funding Structure

\begin{tabular}{|c|c|c|c|c|}
\hline \multirow[b]{2}{*}{ Variable } & \multicolumn{2}{|c|}{$\begin{array}{c}\text { Dependent Variable }=A B S D L L P_{-} A_{i t} \\
(1)\end{array}$} & \multicolumn{2}{|c|}{$\begin{array}{c}\text { Dependent Variable }=A B S D L L P \_B_{i t} \\
(2)\end{array}$} \\
\hline & Coefficient & t-Statistic & Coefficient & t-Statistic \\
\hline Intercept & 0.012 & $13.71 * * *$ & 0.007 & $10.95 * * *$ \\
\hline$C D L_{i t-1}$ & -0.001 & $-11.48 * * *$ & -0.001 & $-14.82 * * *$ \\
\hline$S I Z E_{i t}$ & -0.001 & $-10.37 * * *$ & -0.001 & $-8.02 * * *$ \\
\hline$S I Z E_{i t}^{2}$ & 0.00004 & $9.54 * * *$ & 0.00002 & $6.91 * * *$ \\
\hline$L^{2 O A N} N_{i t}$ & 0.00002 & 0.43 & -0.0001 & $-4.35 * * *$ \\
\hline$C A P R_{i t}$ & -0.001 & $-3.03 * * *$ & -0.001 & $-5.81 * * *$ \\
\hline$E B P_{i t}$ & 0.023 & $5.92 * * *$ & -0.0002 & -0.10 \\
\hline$L L P_{i t-1}$ & 0.157 & $32.55^{* * *}$ & 0.107 & $42.49 * * *$ \\
\hline LIQUID $_{i t}$ & 0.001 & $5.53 * * *$ & 0.0005 & $3.40 * * *$ \\
\hline VOLROA $_{i t}$ & 0.00001 & $3.47 * * *$ & 0.00002 & $4.28 * * *$ \\
\hline$\Delta E B P_{i t+1}$ & -0.041 & $-14.81 * * *$ & -0.027 & $-15.70 * * *$ \\
\hline$P U B L I C_{i t}$ & -0.0002 & $-4.67 * * *$ & -0.0001 & $-3.10 * * *$ \\
\hline$B I G 4_{i t}$ & -0.0001 & -1.11 & 0.00002 & 0.42 \\
\hline Bank, State \& Year Effects & Yes & & Yes & \\
\hline $\mathrm{N}$ & 146,343 & & 146,343 & \\
\hline Adj. $R^{2}$ & 0.178 & & 0.132 & \\
\hline
\end{tabular}

Table 5 provides the regression results for the regression of earnings management on lagged CDL. Continuous variables are winsorized at top and bottom $1 \%{ }^{*}, * *, * * *$ denote significance at the $10 \%, 5 \%$, and $1 \%$ levels, respectively, based on a two-tailed test. Standard errors are clustered at the bank level. Definitions of the variables are provided in Appendix. 
Table 6 Instrumental Variable Analysis of Earnings Quality and Bank Funding Structure

Panel A: First-Stage Regression Results to Predict CDL

\begin{tabular}{l|c|c}
\hline \hline & \multicolumn{2}{|c}{ Dependent Variable $=C D L_{i t}$} \\
\hline Variable & Coefficient & t-Statistic \\
\hline Intercept & 0.597 & $22.28^{* * *}$ \\
\hline$A G E_{i t}$ & 0.019 & $2.95^{* * *}$ \\
\hline$S I Z E_{i t}$ & 0.026 & $-4.61^{* * *}$ \\
\hline$S I Z E_{i t}^{2}$ & -0.002 & $-30.59^{* * *}$ \\
\hline$L O A N_{i t}$ & -0.145 & -0.14 \\
\hline$C A P R_{i t}$ & -0.004 & $-4.74^{* * *}$ \\
\hline$E B P_{i t}$ & -0.842 & $-12.14^{* * *}$ \\
\hline$L L P_{i t-1}$ & -1.718 & $11.36^{* * *}$ \\
\hline$L I Q U I D_{i t}$ & 0.160 & 1.25 \\
\hline$V O L R O A_{i t}$ & 0.001 & $-6.61^{* * *}$ \\
\hline$\Delta E B P_{i t+1}$ & -0.625 & -0.16 \\
\hline$P U B L I C_{i t}$ & -0.001 & $2.38^{* *}$ \\
\hline$B I G 4_{i t}$ & 0.011 & \\
\hline Bank, State \& Year Effects & Yes & \\
\hline $\mathrm{N}$ & & \\
\hline Adj. $R^{2}$ & 146,343 & \\
\hline \hline
\end{tabular}

Panel B: Second-Stage Regression Results for DLLP

\begin{tabular}{|c|c|c|c|c|}
\hline \multirow[b]{2}{*}{ Variable } & \multicolumn{2}{|c|}{$\begin{array}{c}\text { Dependent Variable }=A B S D L L P_{-} A_{i t} \\
(1)\end{array}$} & \multicolumn{2}{|c|}{$\begin{array}{c}\text { Dependent Variable }=A B S D L L P_{-} B_{i t} \\
(2)\end{array}$} \\
\hline & Coefficient & t-Statistic & Coefficient & t-Statistic \\
\hline Intercept & 0.014 & $14.66 * * *$ & 0.010 & $13.32 * * *$ \\
\hline$P R E D \_C D L_{i t-1}$ & -0.004 & $-7.66 * * *$ & -0.004 & $-10.69 * * *$ \\
\hline$S I Z E_{i t}$ & -0.001 & $-9.98 * * *$ & -0.001 & $-7.45 * * *$ \\
\hline$S I Z E_{i t}^{2}$ & 0.00004 & $8.79 * * *$ & 0.00002 & $5.75^{* * *}$ \\
\hline$L O A N_{i t}$ & -0.0005 & $-4.66 * * *$ & -0.001 & $-9.36 * * *$ \\
\hline$C A P R_{i t}$ & -0.001 & $-3.24 * * *$ & -0.001 & $-6.18 * * *$ \\
\hline$E B P_{i t}$ & 0.020 & $5.21 * * *$ & -0.003 & -1.31 \\
\hline$L L P_{i t-1}$ & 0.151 & $30.41 * * *$ & 0.100 & $37.87 * * *$ \\
\hline$L_{L U U I D_{i t}}$ & 0.002 & $7.11 * * *$ & 0.001 & $6.05 * * *$ \\
\hline$V_{O L R O A}$ & 0.00001 & $3.04 * * *$ & 0.00002 & $5.00 * * *$ \\
\hline$\Delta E B P_{i t+1}$ & -0.043 & $-15.36^{* * *}$ & -0.029 & $-16.64 * * *$ \\
\hline$P_{U B L I C}$ & -0.0002 & $-4.72 * * *$ & -0.0001 & $-3.20 * * *$ \\
\hline$B I G 4_{i t}$ & -0.0001 & -0.80 & 0.00004 & 0.89 \\
\hline Bank, State \& Year Effects & Yes & & Yes & \\
\hline $\mathrm{N}$ & 146,343 & & 146,343 & \\
\hline Adj. $R^{2}$ & 0.176 & & 0.130 & \\
\hline
\end{tabular}

Table 6 provides the regression results for the instrumental variable analysis. Panel A provides the first-stage regression results of predicting CDL. Panel B provides the second-stage regression results of DLLP on predicted CDL. Continuous variables are winsorized at top and bottom $1 \%$. *,**,*** denote significance at the $10 \%, 5 \%$, and $1 \%$ levels, respectively, based on a two-tailed test. Standard errors are clustered at the bank level. Definitions of the variables are provided in Appendix. 
Table 7 Retail Deposit Stability, Bank Funding Structure, and Earnings Quality

Panel A: Subsample of Banks with Top Decile Retail Deposit Stability

\begin{tabular}{|c|c|c|c|c|}
\hline \multirow[b]{2}{*}{ Variable } & \multicolumn{2}{|c|}{$\begin{array}{c}\text { Dependent Variable }=A B S D L L P \_A_{i t} \\
(1)\end{array}$} & \multicolumn{2}{|c|}{$\begin{array}{c}\text { Dependent Variable }=A B S D L L P_{-} B_{i t} \\
(2)\end{array}$} \\
\hline & Coefficient & t-Statistic & Coefficient & t-Statistic \\
\hline Intercept & 0.009 & $5.19 * * *$ & 0.006 & $5.00 * * *$ \\
\hline$C D L_{i t-1}$ & -0.002 & $-6.92 * * *$ & -0.001 & $-7.58 * * *$ \\
\hline$S I Z E_{i t}$ & -0.001 & $-3.39 * * *$ & -0.0003 & $-1.96 * * *$ \\
\hline$S I Z E_{i t}^{2}$ & 0.00003 & $2.93 * * *$ & 0.00001 & 1.24 \\
\hline$L_{L A N_{i t}}$ & -0.0002 & $-2.05^{* *}$ & -0.0003 & $-3.48 * * *$ \\
\hline$C A P R_{i t}$ & 0.001 & 0.78 & -0.0003 & -0.66 \\
\hline$E B P_{i t}$ & 0.010 & 1.30 & -0.008 & -1.55 \\
\hline$L L P_{i t-1}$ & 0.150 & $12.30 * * *$ & 0.102 & $14.04 * * *$ \\
\hline$L I Q U I D_{i t}$ & 0.001 & $2.49 * *$ & 0.0002 & 0.45 \\
\hline VOLROA $_{i t}$ & -0.0002 & -1.20 & -0.0001 & -0.51 \\
\hline$\Delta E B P_{i t+1}$ & -0.033 & $-4.27 * * *$ & -0.023 & $-4.45 * * *$ \\
\hline PUBLIC $i t$ & 0.00003 & 0.19 & 0.0001 & 0.76 \\
\hline$B I G 4_{i t}$ & -0.0001 & -0.95 & 0.00004 & 0.42 \\
\hline Bank, State \& Year Effects & Yes & & Yes & \\
\hline $\mathrm{N}$ & 14,624 & & 14,624 & \\
\hline Adj. $R^{2}$ & 0.153 & & 0.124 & \\
\hline
\end{tabular}

Panel B: Subsample of Banks with Bottom Decile Retail Deposit Stability

\begin{tabular}{|c|c|c|c|c|}
\hline \multirow[b]{2}{*}{ Variable } & \multicolumn{2}{|c|}{$\begin{array}{c}\text { Dependent Variable } \\
\text { (1) }\end{array}$} & \multicolumn{2}{|c|}{$\begin{array}{c}\text { Dependent Variable } \\
\text { (2) }\end{array}$} \\
\hline & Coefficient & t-Statistic & Coefficient & t-Statistic \\
\hline Intercept & 0.015 & $6.36 * * *$ & 0.007 & 5.00 \\
\hline$C D L_{i t-1}$ & -0.0001 & -0.19 & 0.0003 & $1.94 *$ \\
\hline$S I Z E_{i t}$ & -0.002 & $-4.19 * * *$ & -0.0003 & -1.40 \\
\hline$S I Z E_{i t}^{2}$ & 0.0001 & $4.34 * * *$ & 0.00001 & 1.56 \\
\hline$L O A N_{i t}$ & 0.0005 & $2.77 * * *$ & -0.00001 & -0.10 \\
\hline$C A P R_{i t}$ & -0.004 & $-4.58 * * *$ & -0.005 & $-7.49 * * *$ \\
\hline$E B P_{i t}$ & 0.040 & $5.27 * * *$ & 0.004 & 0.83 \\
\hline$L L P_{i t-1}$ & 0.139 & $14.66 * * *$ & 0.086 & $15.27 * * *$ \\
\hline$L_{L U U} D_{i t}$ & 0.001 & 1.34 & 0.0005 & 1.16 \\
\hline$V_{O L R O A}$ & 0.00002 & $1.72 *$ & 0.00004 & $6.95 * * *$ \\
\hline$\Delta E B P_{i t+1}$ & -0.028 & $-4.48 * * *$ & -0.028 & $-6.82 * * *$ \\
\hline$P_{U B L I C}$ & -0.0005 & $-3.45 * * *$ & -0.0003 & $-2.88 * * *$ \\
\hline$B I G 4_{i t}$ & -0.000002 & -0.01 & 0.0002 & 1.31 \\
\hline Bank, State \& Year Effects & Yes & & Yes & \\
\hline $\mathrm{N}$ & 14,624 & & 14,624 & \\
\hline Adj. $R^{2}$ & 0.194 & & 0.130 & \\
\hline
\end{tabular}

Table 7 provides the regression results of $D L L P$ on lagged CDL. Panel A provides the regression results for banks with top decile retail deposit stability. Panel B provides the regression results for banks with bottom decile retail deposit stability. Continuous variables are winsorized at top and bottom $1 \%{ }^{*}, * *, * * *$ denote significance at the $10 \%, 5 \%$, and 
$1 \%$ levels, respectively, based on a two-tailed test. Standard errors are clustered at the bank level. Definitions of the variables are provided in Appendix. 
Table 8 Change in Deposit Insurance Limit, Bank Funding Structure, and Earnings Quality

\begin{tabular}{|c|c|c|c|c|}
\hline \multirow[b]{2}{*}{ Variable } & \multicolumn{2}{|c|}{$\begin{array}{c}\text { Dependent Variable }=A B S D L L P_{-} A_{i t} \\
(1)\end{array}$} & \multicolumn{2}{|c|}{$\begin{array}{c}\text { Dependent Variable }=A B S D L L P_{-} B_{i t} \\
(2)\end{array}$} \\
\hline & Coefficient & t-Statistic & Coefficient & t-Statistic \\
\hline Intercept & 0.011 & $6.74 * * *$ & 0.005 & $4.63 * * *$ \\
\hline$C D L_{i t-1}$ & -0.001 & $-4.24 * * *$ & -0.0004 & $-4.45 * * *$ \\
\hline$C D L_{i t-1} * P O S T_{i t}$ & -0.002 & $-6.06 * * *$ & -0.001 & $-7.16^{* * *}$ \\
\hline$S I Z E_{i t}$ & -0.001 & $-3.65 * * *$ & -0.0001 & -0.93 \\
\hline$S I Z E_{i t}^{2}$ & 0.00004 & $3.40 * * *$ & 0.00003 & 0.53 \\
\hline$L_{L A N}$ & -0.0002 & $-2.39 * *$ & -0.0001 & $-1.65^{*}$ \\
\hline$C A P R_{i t}$ & -0.0003 & -0.53 & -0.001 & $-1.96 * *$ \\
\hline$E B P_{i t}$ & -0.014 & $-1.94 * *$ & -0.027 & $-6.28 * * *$ \\
\hline$L L P_{i t-1}$ & 0.158 & $18.70 * * *$ & 0.108 & $21.51 * * *$ \\
\hline LIQUID $_{i t}$ & 0.001 & $3.48 * * *$ & 0.001 & $2.66^{* * *}$ \\
\hline$V_{O L R O A}$ & 0.00003 & $5.14 * * *$ & 0.00003 & $13.86 * * *$ \\
\hline$\Delta E B P_{i t+1}$ & -0.057 & $-10.45^{* * *}$ & -0.038 & $-11.34 * * *$ \\
\hline PUBLIC & -0.0002 & $-1.93 *$ & -0.0001 & -1.63 \\
\hline$B I G 4_{i t}$ & -0.0001 & -0.96 & 0.00003 & 0.67 \\
\hline Bank, State \& Year Effects & Yes & & Yes & \\
\hline $\mathrm{N}$ & 38,523 & & 38,523 & \\
\hline Adj. $R^{2}$ & 0.204 & & 0.176 & \\
\hline
\end{tabular}

Table 8 provides the OLS regression results of DLLP on lagged $C D L$. Continuous variables are winsorized at top and bottom $1 \%{ }^{*}, * *, * * *$ denote significance at the $10 \%, 5 \%$, and $1 \%$ levels, respectively, based on a two-tailed test. Standard errors are clustered at the bank level. Definitions of the variables are provided in Appendix. 
Table 9 Alternative Measures of Earnings Quality and Bank Funding Structure

Panel A: Regression Results for Income-Increasing DLLP

\begin{tabular}{|c|c|c|c|c|}
\hline \multirow[b]{2}{*}{ Variable } & \multicolumn{2}{|c|}{$\begin{array}{c}\text { Dependent Variable }=\text { ABSIIDLLP_A } A_{i t} \\
(1)\end{array}$} & \multicolumn{2}{|c|}{$\begin{array}{c}\text { Dependent Variable }=A B S I I D L L P_{-} A_{i t} \\
(2)\end{array}$} \\
\hline & Coefficient & t-Statistic & Coefficient & t-Statistic \\
\hline Intercept & 0.006 & $15.33 * * *$ & 0.007 & $10.31 * * *$ \\
\hline$C D L_{i t-1}$ & -0.0004 & $-8.54 * * *$ & -0.001 & $-10.82 * * *$ \\
\hline$S I Z E_{i t}$ & -0.0003 & $-5.33 * * *$ & -0.001 & $-6.24 * * *$ \\
\hline$S I Z E_{i t}^{2}$ & 0.00001 & $5.45^{* * *}$ & 0.00002 & $5.79 * * *$ \\
\hline$L^{2} A_{i t}$ & -0.0002 & $-9.22 * * *$ & -0.0004 & $-8.89 * * *$ \\
\hline$C A P R_{i t}$ & -0.002 & $-13.90 * * *$ & -0.002 & $-8.42 * * *$ \\
\hline$E B P_{i t}$ & -0.018 & $-13.43 * * *$ & -0.016 & $-6.91 * * *$ \\
\hline$L L P_{i t-1}$ & 0.005 & $2.73 * * *$ & 0.079 & $25.53 * * *$ \\
\hline$L_{I Q U I D_{i t}}$ & 0.0002 & $2.50 * *$ & 0.0003 & $1.68^{*}$ \\
\hline VOLROA $_{i t}$ & -0.00001 & $-2.38 * *$ & 0.000004 & 1.02 \\
\hline$\Delta E B P_{i t+1}$ & -0.005 & $-4.29 * * *$ & -0.011 & $-5.70 * * *$ \\
\hline PUBLIC & -0.0001 & $-4.22 * * *$ & -0.0001 & $-3.58 * * *$ \\
\hline$B I G 4_{i t}$ & 0.00001 & 0.22 & 0.00001 & 0.29 \\
\hline Bank, State \& Year Effects & Yes & & Yes & \\
\hline $\mathrm{N}$ & 100,463 & & 81,504 & \\
\hline Adj. $R^{2}$ & 0.305 & & 0.106 & \\
\hline
\end{tabular}

Panel B: Regression Results for Income-Decreasing DLLP

\begin{tabular}{|c|c|c|c|c|}
\hline \multirow[b]{2}{*}{ Variable } & \multicolumn{2}{|c|}{$\begin{array}{c}\text { Dependent Variable }=A B S I D D L L P_{-} B_{i t} \\
(1)\end{array}$} & \multicolumn{2}{|c|}{$\begin{array}{c}\text { Dependent Variable }=A B S I D D L L P_{-} B_{i t} \\
(2)\end{array}$} \\
\hline & Coefficient & t-Statistic & Coefficient & t-Statistic \\
\hline Intercept & 0.018 & $9.62 * * *$ & 0.007 & $8.26 * * *$ \\
\hline$C D L_{i t-1}$ & -0.002 & $-9.72 * * *$ & -0.001 & $-10.87 * * *$ \\
\hline$S I Z E_{i t}$ & -0.002 & $-8.72 * * *$ & -0.001 & $-5.57 * * *$ \\
\hline$S I Z E_{i t}^{2}$ & 0.0001 & $7.69 * * *$ & 0.00002 & $4.21 * * *$ \\
\hline $\operatorname{LOAN}_{i t}$ & 0.0001 & 0.87 & 0.00003 & 0.54 \\
\hline$C A P R_{i t}$ & 0.001 & 1.03 & -0.0003 & -0.93 \\
\hline$E B P_{i t}$ & 0.048 & $7.10^{* * *}$ & 0.012 & $3.81 * * *$ \\
\hline$L L P_{i t-1}$ & 0.209 & $29.49 * * *$ & 0.120 & $31.83 * * *$ \\
\hline$L I Q U I D_{i t}$ & 0.003 & $5.21 * * *$ & 0.001 & $3.51 * * *$ \\
\hline$V_{O L R O A}$ & 0.00002 & $3.98 * * *$ & 0.00002 & $5.44 * * *$ \\
\hline$\Delta E B P_{i t+1}$ & -0.067 & $-12.35 * * *$ & -0.041 & $-14.79 * * *$ \\
\hline$P_{U B L I C}$ & -0.0003 & $-2.67 * * *$ & -0.0001 & -1.14 \\
\hline$B I G 4_{i t}$ & -0.0003 & $-2.08 * *$ & -0.00001 & -0.18 \\
\hline Bank, State \& Year Effects & Yes & & Yes & \\
\hline $\mathrm{N}$ & 45,880 & & 64,839 & \\
\hline Adj. $R^{2}$ & 0.217 & & 0.184 & \\
\hline
\end{tabular}




\section{Table 9 (Continued)}

Panel C: Regression Results for Loss Avoidance

\begin{tabular}{|c|c|c|}
\hline & \multicolumn{2}{|c|}{$\begin{array}{c}\text { Dependent Variable }=L S A V_{i t} \\
(1)\end{array}$} \\
\hline Variable & Coefficient & t-Statistic \\
\hline Intercept & 3.195 & $5.59 * * *$ \\
\hline$C D L_{i t-1}$ & -0.617 & $-7.97 * * *$ \\
\hline$S I Z E_{i t}$ & -0.584 & $-6.14 * * *$ \\
\hline$S I Z E_{i t}^{2}$ & 0.017 & $4.25 * * *$ \\
\hline$L_{L A N_{i t}}$ & -0.530 & $-11.56^{* * *}$ \\
\hline$C A P R_{i t}$ & 0.857 & $3.75 * * *$ \\
\hline$E B P_{i t}$ & -55.528 & $-26.79 * * *$ \\
\hline$L L P_{i t-1}$ & 10.351 & $6.14 * * *$ \\
\hline$L I Q U I D_{i t}$ & -0.156 & -1.12 \\
\hline VOLROA $_{i t}$ & 0.002 & $1.68^{*}$ \\
\hline$\Delta E B P_{i t+1}$ & -8.914 & $-6.17 * * *$ \\
\hline PUBLIC & -0.006 & -0.12 \\
\hline$B I G 4_{i t}$ & -0.062 & -0.97 \\
\hline Bank, State \& Year Effects & Yes & \\
\hline $\mathrm{N}$ & 146,343 & \\
\hline Pseudo. $R^{2}$ & 0.110 & \\
\hline
\end{tabular}

Panel D: Regression Results for Income-Smoothing Test

\begin{tabular}{l|c|c}
\hline \hline & \multicolumn{2}{|c}{$\begin{array}{c}\text { Dependent Variable }=L L P_{i t} \\
(1)\end{array}$} \\
\hline Variable & Coefficient & $\mathrm{t}-$ Statistic \\
\hline Intercept & 0.008 & $6.67^{* * *}$ \\
\hline$E B P_{i t}$ & 0.179 & $6.20^{* * *}$ \\
\hline$C D L_{i t-1}$ & -0.001 & $-5.54^{* * *}$ \\
\hline$E B P_{i t} * C L_{i t-1}$ & -0.089 & $-2.62^{* * *}$ \\
\hline$S I Z E_{i t}$ & -0.002 & $-11.06^{* * *}$ \\
\hline$S I Z E_{i t}^{2}$ & 0.000 & $10.71^{* * *}$ \\
\hline$L O A N_{i t}$ & 0.002 & $18.69^{* * *}$ \\
\hline$\Delta L O A N_{i t}$ & 0.002 & $9.57^{* * *}$ \\
\hline$L L P_{i t-1}$ & 0.252 & $39.06^{* * *}$ \\
\hline$N P L_{i t-1}$ & 0.017 & $13.72^{* * *}$ \\
\hline$\Delta N P L_{i t}$ & 0.0002 & $1.92^{* * *}$ \\
\hline$C A P R_{i t}$ & 0.003 & $6.48^{* * *}$ \\
\hline$P U B L I C_{i t}$ & -0.0002 & $-2.81^{* * *}$ \\
\hline$B I G 4_{i t}$ & -0.00003 & -0.33 \\
\hline Bank, State \& Year Effects & Yes & \\
\hline $\mathrm{N}$ & & \\
\hline Adj. $R^{2}$ & 146,343 & \\
\hline \hline
\end{tabular}

Table 9 provides the regression results using alternative measures of earnings quality. Panels A and B provide the OLS regression results of income-increasing and income-decreasing $D L L$ on core deposits, respectively. Panel C provides the probit regression results of loss avoidance on core deposits. Panel D provides the OLS regression results of income 
smoothing on core deposits. Continuous variables are winsorized at top and bottom $1 \%$. *,**,*** denote significance at the $10 \%, 5 \%$, and $1 \%$ levels, respectively, based on a two-tailed test. Standard errors are clustered at the bank level. Definitions of the variables are provided in Appendix. 
Table 10 Earnings Quality and Bank Funding Structure in Different Sample Periods

\section{Panel A: Pre-Crisis Period}

\begin{tabular}{|c|c|c|c|c|}
\hline \multirow[b]{2}{*}{ Variable } & \multicolumn{2}{|c|}{$\begin{array}{c}\text { Dependent Variable }=A B S D L L P \_A_{i t} \\
(1)\end{array}$} & \multicolumn{2}{|c|}{$\begin{array}{c}\text { Dependent Variable }=A B S D L L P_{-} B_{i t} \\
(2)\end{array}$} \\
\hline & Coefficient & t-Statistic & Coefficient & t-Statistic \\
\hline Intercept & 0.012 & $13.57 * * *$ & 0.008 & $12.47 * * *$ \\
\hline$C D L_{i t-1}$ & -0.001 & $-7.91 * * *$ & -0.001 & $-10.80 * * *$ \\
\hline$S I Z E_{i t}$ & -0.001 & $-10.77 * * *$ & -0.001 & $-10.28 * * *$ \\
\hline$S I Z E_{i t}^{2}$ & 0.00005 & $9.87 * * *$ & 0.00003 & $9.07 * * *$ \\
\hline$L_{L A N_{i t}}$ & 0.0002 & $3.70 * * *$ & -0.0001 & $-2.67 * * *$ \\
\hline$C A P R_{i t}$ & -0.001 & $-4.24 * * *$ & -0.002 & $-7.24 * * *$ \\
\hline$E B P_{i t}$ & 0.046 & $11.47 * * *$ & 0.017 & $8.19 * * *$ \\
\hline$L L P_{i t-1}$ & 0.153 & $26.37 * * *$ & 0.098 & $34.46 * * *$ \\
\hline$L I Q U I D_{i t}$ & 0.001 & $3.77 * * *$ & 0.001 & $3.37 * * *$ \\
\hline VOLROA $_{i t}$ & -0.00001 & $-2.53 * *$ & 0.000002 & 0.72 \\
\hline$\Delta E B P_{i t+1}$ & -0.031 & $-10.85 * * *$ & -0.020 & $-11.48 * * *$ \\
\hline PUBLIC $i t$ & -0.0002 & $-5.43 * * *$ & -0.0001 & $-2.69 * * *$ \\
\hline$B I G 4_{i t}$ & -0.0001 & $-2.78 * * *$ & -0.0001 & $-2.54 * *$ \\
\hline Bank, State \& Year Effects & Yes & & Yes & \\
\hline $\mathrm{N}$ & 109,566 & & 109,566 & \\
\hline Adj. $R^{2}$ & 0.151 & & 0.102 & \\
\hline
\end{tabular}

Panel B: Crisis Period

\begin{tabular}{|c|c|c|c|c|}
\hline \multirow[b]{2}{*}{ Variable } & \multicolumn{2}{|c|}{$\begin{array}{c}\text { Dependent Variable } \\
\text { (1) }\end{array}$} & \multicolumn{2}{|c|}{$\begin{array}{c}\text { Dependent Variable }=A B S D L L P_{-} B_{i t} \\
(2)\end{array}$} \\
\hline & Coefficient & t-Statistic & Coefficient & t-Statistic \\
\hline Intercept & 0.009 & $3.85 * * *$ & 0.004 & $2.49 * *$ \\
\hline$C D L_{i t-1}$ & -0.002 & $-5.89 * * *$ & -0.001 & $-7.35^{* *}$ \\
\hline$S I Z E_{i t}$ & -0.001 & $-2.23 * *$ & -0.00004 & -0.18 \\
\hline$S I Z E_{i t}^{2}$ & 0.00003 & $2.10^{* *}$ & -0.000001 & -0.07 \\
\hline$L O A N_{i t}$ & -0.0004 & $-2.59 * * *$ & -0.00005 & -0.47 \\
\hline$C A P R_{i t}$ & 0.001 & 0.72 & -0.0005 & -0.75 \\
\hline$E B P_{i t}$ & -0.008 & -0.84 & -0.029 & $-4.71 * * *$ \\
\hline$L L P_{i t-1}$ & 0.199 & $13.75 * * *$ & 0.129 & $15.59 * * *$ \\
\hline$L I Q U I D_{i t}$ & 0.001 & 1.47 & 0.0004 & 0.99 \\
\hline$V_{O L R O A}$ & 0.00004 & $8.55 * * *$ & 0.00004 & $8.79 * * *$ \\
\hline$\Delta E B P_{i t+1}$ & -0.061 & $-9.05 * * *$ & -0.043 & $-10.28 * * *$ \\
\hline PUBLIC & -0.0002 & -1.13 & -0.0001 & -0.65 \\
\hline$B I G 4_{i t}$ & -0.0001 & -0.50 & 0.00005 & 0.50 \\
\hline Bank, State \& Year Effects & Yes & & Yes & \\
\hline $\mathrm{N}$ & 19,009 & & 19,009 & \\
\hline Adj. $R^{2}$ & 0.178 & & 0.154 & \\
\hline
\end{tabular}




\section{Table 10 (Continued)}

Panel C: Post-Crisis Period

\begin{tabular}{|c|c|c|c|c|}
\hline \multirow[b]{2}{*}{ Variable } & \multicolumn{2}{|c|}{$\begin{array}{c}\text { Dependent Variable } \\
(1)\end{array}$} & \multicolumn{2}{|c|}{$\begin{array}{c}\text { Dependent Variable }=A B S D L L P_{-} B_{i t} \\
(2)\end{array}$} \\
\hline & Coefficient & t-Statistic & Coefficient & t-Statistic \\
\hline Intercept & 0.009 & $4.20 * * *$ & 0.012 & $13.57 * * *$ \\
\hline$C D L_{i t-1}$ & -0.001 & $-5.86 * * *$ & -0.001 & $-7.91 * * *$ \\
\hline$S I Z E_{i t}$ & -0.001 & $-2.82 * * *$ & -0.001 & $-10.77 * * *$ \\
\hline$S I Z E_{i t}^{2}$ & 0.00003 & $2.60 * * *$ & 0.00005 & $9.87 * * *$ \\
\hline$L_{L A N}$ & -0.0004 & $-2.95 * * *$ & 0.0002 & $3.70 * * *$ \\
\hline$C A P R_{i t}$ & 0.001 & 1.64 & -0.001 & $-4.24 * * *$ \\
\hline$E B P_{i t}$ & -0.027 & $-2.84 * * *$ & 0.046 & $11.47 * * *$ \\
\hline$L L P_{i t-1}$ & 0.113 & $14.44 * * *$ & 0.153 & $26.37 * * *$ \\
\hline$L I Q U I D_{i t}$ & 0.001 & $3.55 * * *$ & 0.001 & $3.77 * * *$ \\
\hline VOLROA $_{i t}$ & -0.000001 & -0.39 & -0.00001 & $-2.53 * *$ \\
\hline$\Delta E B P_{i t+1}$ & -0.035 & $-4.36 * * *$ & -0.031 & $-10.85 * * *$ \\
\hline$P_{U B L I C_{i t}}$ & -0.0002 & -1.58 & -0.0002 & $-5.43 * * *$ \\
\hline$B I G 4_{i t}$ & 0.0001 & 0.69 & -0.0001 & $-2.78 * * *$ \\
\hline Bank, State \& Year Effects & Yes & & Yes & \\
\hline $\mathrm{N}$ & 17,786 & & 17,786 & \\
\hline Adj. $R^{2}$ & 0.140 & & 0.128 & \\
\hline
\end{tabular}

Table 10 provides the OLS regression results of $D L L P$ on $C D L$ in different sample periods. Panels $\mathrm{A}, \mathrm{B}$, and $\mathrm{C}$ provide the results for pre-crisis, crisis, and post-crisis periods, respectively. Continuous variables are winsorized at top and bottom $1 \%{ }^{*}, * *, * * *$ denote significance at the $10 \%, 5 \%$, and $1 \%$ levels, respectively, based on a two-tailed test. Standard errors are clustered at the bank level. Definitions of the variables are provided in Appendix. 
Figure 1 Path Analysis of the Relations among Funding Structure, Mediating Variable, and Earnings Quality
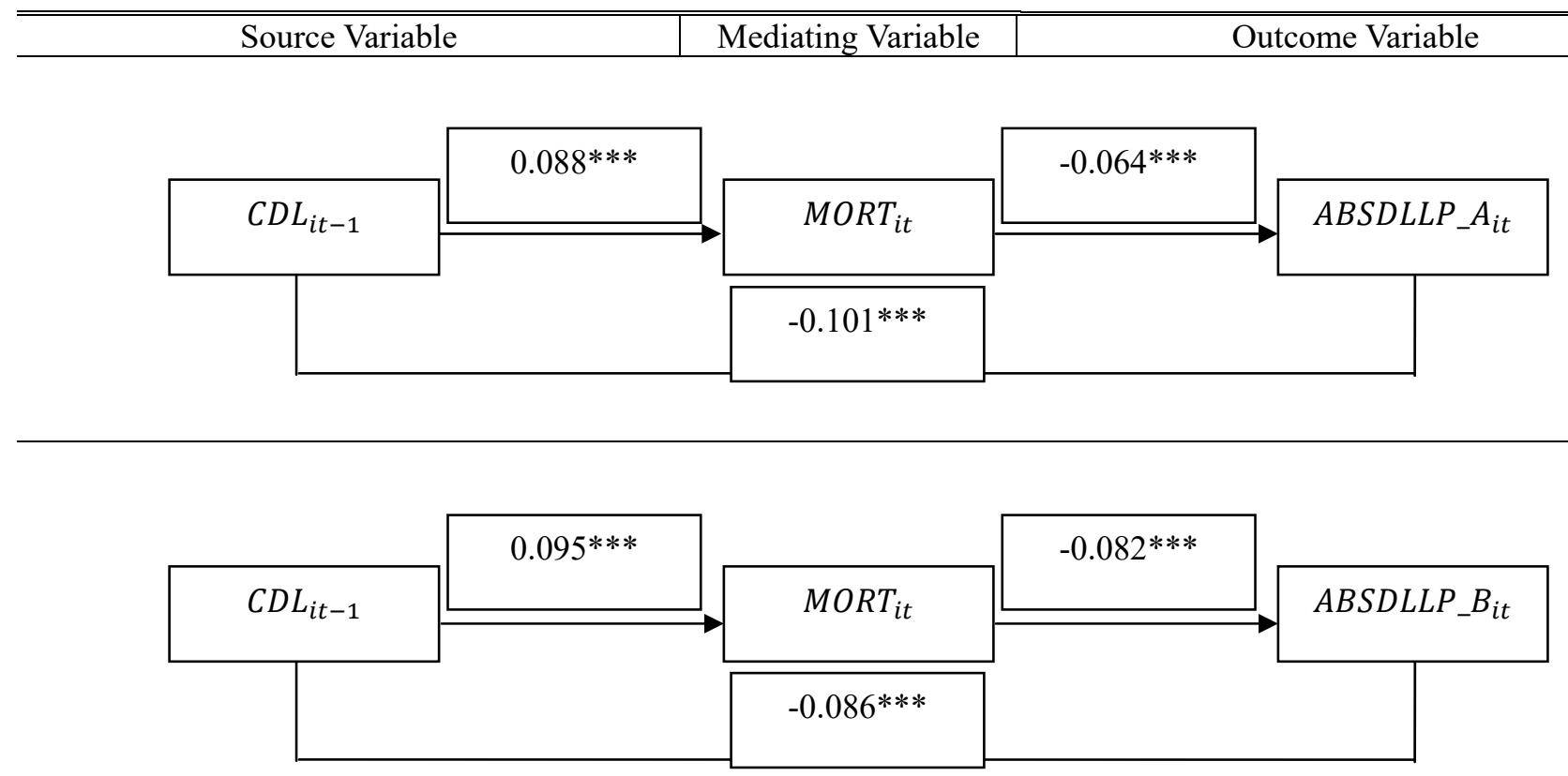

Figure 1 provides the path analysis of the relations between the funding structure variable $C D L$ and the bank earnings quality variable $A B S D L L P$ : the direct effect between the two variables, and the indirect effect through mortgage lending (MORT). *, **,*** denote significance at the $10 \%, 5 \%$, and $1 \%$ levels, respectively, based on a two-tailed test. Definitions of the variables are provided in Appendix. 